\title{
Extracellular Vesicles in Lung Cancer Metastasis and Their Clinical Applications
}

\author{
Michela Saviana ${ }^{1,2,+}$, Giulia Romano ${ }^{1,+}$, Patricia Le ${ }^{1}$, Mario Acunzo ${ }^{1}$ and Patrick Nana-Sinkam ${ }^{1, *}$ \\ 1 Department of Internal Medicine, Division of Pulmonary Diseases and Critical Care Medicine, \\ Virginia Commonwealth University, Richmond, VA 23298, USA; michela.saviana@vcuhealth.org (M.S.); \\ giulia.romano@vcuhealth.org (G.R.); patricia.le@vcuhealth.org (P.L.); mario.acunzo@vcuhealth.org (M.A.) \\ 2 Department of Molecular Medicine, University La Sapienza, 00161 Rome, Italy \\ * Correspondence: patrick.nana-sinkam@vcuhealth.org \\ + Contributed equally.
}

check for updates

Citation: Saviana, M.; Romano, G.; Le, P.; Acunzo, M.; Nana-Sinkam, P. Extracellular Vesicles in Lung Cancer Metastasis and Their Clinical Applications. Cancers 2021, 13, 5633. https://doi.org/10.3390/ cancers 13225633

Academic Editor: Lyndsay Rhodes

Received: 14 October 2021

Accepted: 9 November 2021

Published: 11 November 2021

Publisher's Note: MDPI stays neutral with regard to jurisdictional claims in published maps and institutional affiliations.

Copyright: (c) 2021 by the authors. Licensee MDPI, Basel, Switzerland. This article is an open access article distributed under the terms and conditions of the Creative Commons Attribution (CC BY) license (https:// creativecommons.org/licenses/by/ $4.0 /)$.
Simple Summary: Cancer cells are known to interact with the surrounding extracellular environment to facilitate tumorigenic processes. One mechanism by which cancer cells communicate with each other and their environment is through extracellular vesicles. These vesicles contain various biological molecules that are secreted by parental cells for delivery to target recipient cells. Over the past several decades, knowledge of the structure and contents of extracellular vesicles has provided valuable insight into tumor biology. Considering this information, researchers have begun examining the potential of these vesicles for developing novel biomarker classifiers as well as therapeutic strategies.

Abstract: Extracellular vesicles (EVs) are heterogenous membrane-encapsulated vesicles secreted by every cell into the extracellular environment. EVs carry bioactive molecules, including proteins, lipids, DNA, and different RNA forms, which can be internalized by recipient cells, thus altering their biological characteristics. Given that EVs are commonly found in most body fluids, they have been widely described as mediators of communication in several physiological and pathological processes, including cancer. Moreover, their easy detection in biofluids makes them potentially useful candidates as tumor biomarkers. In this manuscript, we review the current knowledge regarding EVs and non-coding RNAs and their role as drivers of the metastatic process in lung cancer. Furthermore, we present the most recent applications for EVs and non-coding RNAs as cancer therapeutics and their relevance as clinical biomarkers.

Keywords: extracellular vesicles; metastasis; lung cancer; non-coding RNA; therapy

\section{Introduction}

Despite the advent of targeted therapeutics, immunotherapy, and strategies for early detection, the battle against cancer wages on. In the past two decades, investigators have identified small and ubiquitous particles termed extracellular vesicles (EVs) that appear to play an increasing role in the development of several diseases, including cancer. EVs are small vesicles containing cytoplasmic constituents, including proteins, lipids, and nucleic acids. Constitutively released by every cell [1,2], EVs are freely transported throughout the circulatory system, where they can interact with cells in both the micro- and macroenvironment. EVs have been detected in various biological fluids, including blood, cerebrospinal fluids, bronchoalveolar fluid, breast milk, urine, and saliva [3-8], raising their potential as clinically relevant biomarkers.

To date, investigators have demonstrated that EVs play roles in a broad scope of biological and pathological processes [1]. EV-mediated delivery of biological effectors is often essential to the maintenance of cell physiology. EVs are involved in signaling that controls immune responses, by triggering or suppressing inflammation [9-17]. Moreover, EVs are 
released in the brain in a synaptic-dependent way, and allow for neural communication [18]. Also, EVs are involved in tissue repair, coagulation, and stem cell maintenance [19-21].

In cancer, investigators have implicated EV biology in many malignant processes, including inflammatory responses, cell proliferation, migration, invasion, angiogenesis, epithelial-to-mesenchymal transition, and the formation of pre-metastatic niches [22-24].

Lung cancer remains as one of the most prevalent malignancies across the world, accounting for more deaths than any other reported malignancy [25]. For 2021, the American Cancer Society estimates that 235,000 new cases and 131,000 deaths will result from lung cancer in the United States alone [26]. This disease has two distinct histological subtypes: non-small cell lung cancer (NSCLC) (76\% of lung cancer cases) and small cell lung cancer (SCLC) (13\% of lung cancer cases) [27]. Tobacco smoking is linked to approximately $90 \%$ of lung cancers and contributes to the high mutational burden often observed with this malignancy [28]. Notably, there is an increasing population of never-smokers who are being diagnosed with lung cancer as well [25]. Overall, the five-year survival rates are dismal at $\sim 20 \%$, but the overall mortality rates have declined; this trend is likely driven by decreased incidence, improvements in screening criteria and implementation, increased sensitivity of imaging modalities, and more effective chemotherapeutics and treatment regimens (immunotherapy, targeted drugs against EGFR and ALK) $[25,27,29,30]$. In light of this recent progress in lung cancer screening and treatment, patients are still often diagnosed at a late stage, at which point therapies with meaningful long-term responses are limited, and even with treatment, these patients often succumb to metastatic disease [26,31,32].

Increasing our understanding of EV-mediated cell-to-cell communication and EV contents may prove valuable in elucidating additional mechanisms for lung cancer metastases and clinical biomarkers [33]. In this manuscript, we review the role of EVs in lung cancer metastasis and the implications for lung cancer therapies.

\section{Types and Characteristics of EVs}

EVs were first identified in 1946 [34] and were initially considered to be essential for physiological activities such as the cellular elimination of cytotoxic materials [35]. A few years later, their role as mediators of intercellular communication began to be studied, with the discovery that EVs harbor important bioactive molecules, such as nucleic acids [36], which can be internalized by recipient cells, consequently perturbing their biological phenotype [35].

Currently, three main types of EVs have been characterized based on differences in their size, biogenesis, and mechanism of release (see Table 1).

Table 1. Main types and characteristics of extracellular vesicles.

\begin{tabular}{cccc}
\hline Variable & Exosomes & Microvesicles & Apoptotic Bodies \\
\hline Size $(\mathrm{nm})$ & $50-150$ & $100-2000$ & $1000-4000$ \\
Biogenesis & Endosomal pathway & Budding of plasma membrane & $\begin{array}{c}\text { Programmed cell death and } \\
\text { blebbing of plasma membrane }\end{array}$ \\
Proteins & $\begin{array}{c}\text { Tetraspanins, ALIX, TSG101, ESCRT, } \\
\text { heat shock proteins }\end{array}$ & $\begin{array}{c}\text { Integrins, selectins, } \\
\text { cytoskeletal and cytosolic } \\
\text { proteins, glycosylated and } \\
\text { phosphorylated proteins }\end{array}$ & Histones, annexin V \\
\hline Lipids & $\begin{array}{c}\text { Cholesterol, sphingomyelin, } \\
\text { ceramide, lipid rafts, } \\
\text { phosphatidylserine }\end{array}$ & $\begin{array}{c}\text { Phosphatidylserine, } \\
\text { cholesterol, diacylglycerol, } \\
\text { lipid rafts }\end{array}$ & Phosphatidylserine \\
\hline Nucleic acids & mRNA, non-coding RNA & mRNA, non-coding RNA & DNA, RNA \\
\hline Markers & CD63, TSG101, Alix, tetraspanins, \\
Rab5a/b, HSP70, HSP9 & Integrin, selectin, flittilin-2 & Histones, DNA, Annexin V \\
\hline
\end{tabular}




\subsection{Biogenesis and Release}

Exosomes: Exosome biogenesis involves the endosomal system and is driven by the endosomal sorting complex required for transport (ESCRT) [37,38]; Rab GTPases (including Rab7A, Rab11, Rab27A, Rab27B, and Rab35), ALG-2-interacting protein X (ALIX), and vacuolar protein sorting-associated protein (VPS4) are support factors contributing to ESCRT regulation and exosomes release [39]. Exosome biogenesis may also occur in an ESCRT-independent manner, in which proteins including tetraspanins are involved $[40,41]$.

Exosome release is mediated by lipid-protein and protein-protein interactions that coordinate fusion with the plasma membrane. Among the proteins involved in this process, SNAREs and Rab GTPases are the most studied [42-45]. Exosome release is also regulated by environmental factors, including stress-related conditions; indeed, it has been reported that irradiation, hypoxia exposure, and cisplatin treatment increase exosome secretion [46-50].

Microvesicles: MVs originate from the direct budding of the plasma membrane. This mechanism has yet to be fully defined, but it appears to be mediated by ADP-ribosylation factor 6 (ARF6) and RHOA-dependent rearrangement of the actin cytoskeleton [51]. The redistribution of phospholipids and phosphatidylserine, as well as actin contraction, are crucial factors for MV formation [52-55].

Apoptotic bodies (ABs): ABs are a product of cell disassembly via blebbing, which occurs exclusively after programmed cell death (apoptosis) [52]. The morphological formation of ABs occurs in three main steps [56]:

1. Membrane blebbing

2. Membrane protrusion formation

3. Apoptotic bodies formation

Although our knowledge of the molecular mechanisms of blebbing remains unclear [57], the formation of ABs concludes with the detachment of vesicles that are 1-5 $\mu \mathrm{m}$ in diameter.

\subsection{EV Cargo}

The EV cargo reflects the status, or molecular fingerprint, of the cells from which they originate. Contents of EVs include DNA (double-strand DNA, single-strand DNA, mitochondrial DNA), RNA (coding RNA, non-coding RNA), proteins, and lipids.

Proteins: Proteomic studies have demonstrated that the EV protein cargo is dependent on the type of EVs from which they originate [58]. One of the biggest challenges in EV characterization is identifying specific biological markers that can distinguish them from one another. Proteins that are essential to biogenesis and release of EVs are consistently present [58-61]. For example, ESCRT and its accessory proteins (Alix, TSG101, HSC70, and HSP90 $\beta$ ) are commonly found in exosomes [39,61-65], as well as glycosylated proteins and proteins of the tetraspanin family [40,66-68]. MVs appear to be enriched with posttranslational modifications, such as palmitoylation and myristoylation, which can help drive the loading of proteins into MVs $[69,70]$. MVs also contain proteins associated with microtubules and cytoskeleton networks [58,71], as well as integrins, heat shock proteins, and metalloproteinases [71-74]. Investigators have also identified some transcriptional factors within MVs [75]. Unlike MVs and exosomes, ABs contain whole organelles; therefore, the presence of proteins from mitochondria (HSP60), the nucleus (histones), Golgi apparatus, and endoplasmic reticulum is expected [61].

Lipids: A variety of lipids contained in EVs share common features with the parental cell, and thus, EV lipid composition depends on the typology of the donor cell [76]. However, some peculiar findings have been reported, including the enrichment of exosomal cholesterol, sphingomyelin, glycosphingolipids, and phosphatidylserine [77]. Wubbolts et al. were the first to describe exosomes as vesicles enriched in cholesterol and sphingolipids with properties similar to raft lipids [78]. Moreover, in a study that focused on the lipidomic characterization of EVs secreted by platelets, lipidic composition varied in accordance with the dimension of the vesicles [79]. 
Nucleic acids: Both RNA and DNA have been detected in EVs [59,62,77]; however, DNA has been observed more frequently in large vesicles compared to exosomes [80]. Overall, RNA molecules and principally small RNAs are the predominant nucleic acids transported within EVs. The RNA species in EVs have been examined using high-throughput RNA sequencing, identifying the presence of both protein-coding RNAs (mRNA) and non-coding RNAs (ncRNAs). Most of the RNA population contained in EVs are ncRNAs, including long non-coding RNA (lncRNA), microRNA (miRNA), ribosomal RNA (rRNA), transfer RNA (tRNA), circular RNA (circRNA), small nuclear RNA (snRNA), small nucleolar RNA (snoRNA), and piwi-interacting RNA (piRNA) [81-83]. In general, the profile of EV RNA is reflective of the donor cell; however, some differences have been described. For instance, some lncRNAs are enriched in EVs compared to the parental cell [84], although the mechanism of their sorting in EVs is not yet understood. A microarray study directed to identify mRNA in EVs demonstrated that some mRNAs contained in exosomes are not detected within the cells from which they originate [36]. Another study reported that many miRNAs were particularly abundant in EVs, while others were preferentially expressed in the cells [85]. Comparing the sequences of these miRNAs, the authors concluded that some specific sequences of miRNAs might facilitate their loading into EVs. Among these, the sequences GGAG and C/UCCU/G contribute to miRNA sorting, and their mutations prevent the accumulation of miRNAs in EVs. This process is regulated by the heterogeneous nuclear ribonucleoprotein A2B1 (hnRNPA2B1), which recognizes and interacts with miRNAs containing EXOmotifs, thereby acting to control loading into EVs [85]. hnRNPA2B1 has also been found to be sumoylated in exosomes, which appears to be crucial for binding the miRNAs [85].

\subsection{EV Internalization}

The mechanisms for EV internalization remain unclear and require further examination. To date, two main mechanisms for the internalization of EVs have been proposed: endocytosis and fusion with the plasma membrane [59]. EV uptake requires proteins to interact with membrane receptors on target cells in order to facilitate endocytosis [86-89]. Among these, tetraspanins, integrins, proteoglycans, immunoglobulins, and lectins have been shown to be implicated in EV internalization [90].

Overall, the manner of uptake depends on the recipient cell typology, cell status, and whether or not the cells express the receptors for the EV ligand [59,91]. Moreover, the typology and membrane composition of the EV may affect their uptake.

\section{EVs in Lung Cancer Metastasis}

To disseminate to distant organs, circulating tumor cells (CTCs) require localization to the right "soil", namely a permissive microenvironment in terms of extracellular matrix structure and immune cell presence. The "seed and soil" theory was first described by Stephen Paget during the course of analyzing post-mortem data of breast cancer when he noticed that breast cancer metastases only appeared in specific organs [92,93]. Since his initial observation, investigators have recognized that some types of cancer, including lung cancers, metastasize to preferential distant sites. For example, in lung cancer, the preferential metastatic sites are the brain, thoracic wall, bones, and liver [94-99].

A new interpretation of the "seed and soil" theory has suggested that EVs are secreted as "seeds" by cancer cells [100]. Once the EVs enter the circulation, they can reach distant organs and release factors directly into the recipient cells, modifying the gene expression and creating a permissive and immunosuppressive microenvironment, usually known as a pre-metastatic niche [101,102].

\subsection{Biology of Metastasis}

Metastasis is a complex multistage process (Figure 1) that begins with the detachment of tumor cells from the extracellular matrix, followed by their colonization of the surrounding tissues; this process marks the transition from a benign nodule to an invasive 
malignant tumor [103]. In order to cross the basement membrane and basal lamina, cells undergo a functional and morphological change through epithelial-to-mesenchymal transition (EMT). EMT is characterized by the downregulation of key epithelial proteins, such as the E-cadherin, which are involved in epithelial cell-cell adhesion [104]. Furthermore, EMT is marked by the acquisition of actin-based membrane protrusions that promote cell migration [105]. Cancer cells also gain the ability to degrade the extracellular matrix by secreting matrix metalloproteases (MMPs); this starts the invasion process and triggers a local inflammatory response by recruiting lymphocytes, neutrophils, macrophages, and dendritic cells [103]. Following tumor growth, cancer cells form new vessels via angiogenesis to better access oxygen and nutrients from the bloodstream and to promote intravasation into the circulatory or lymphatic system (lymphangiogenesis) [106].

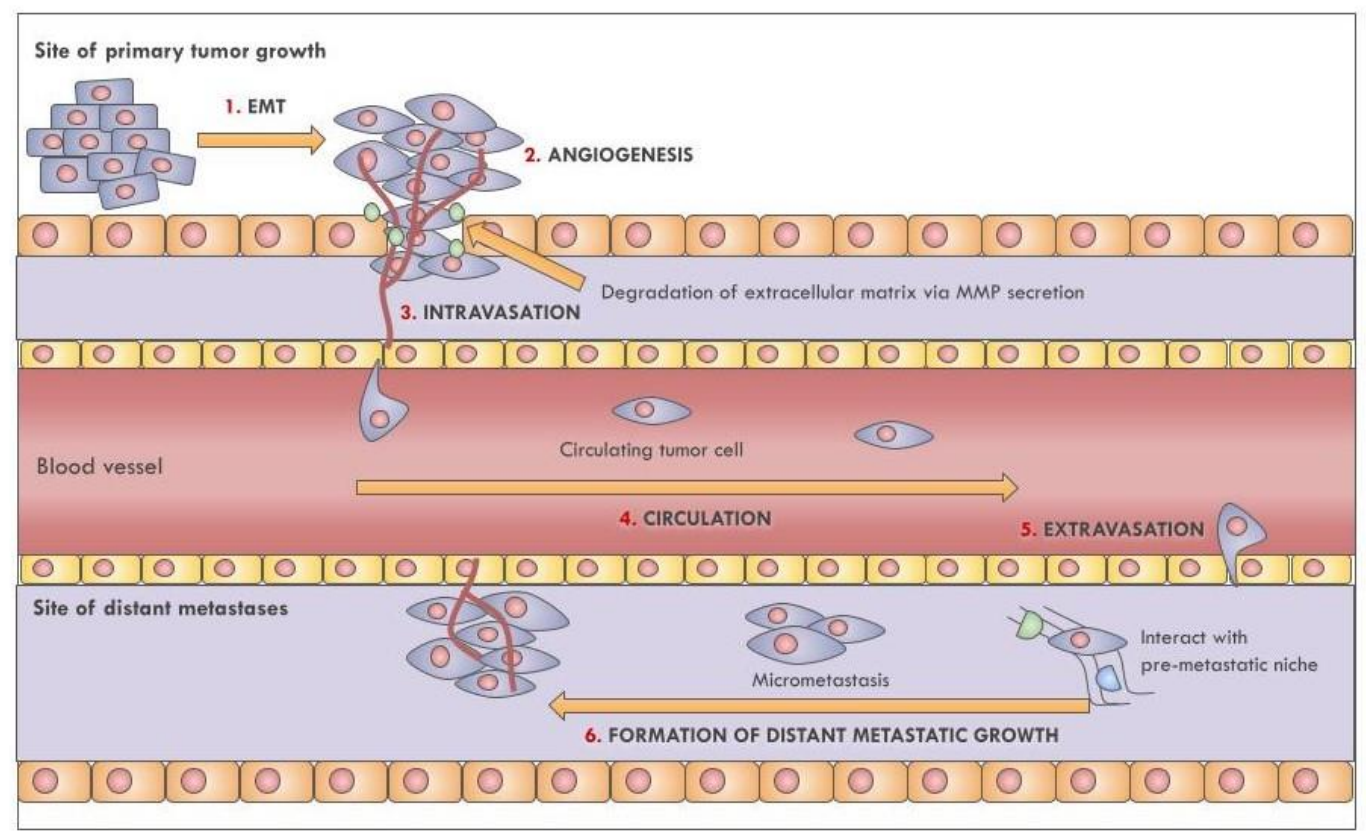

Figure 1. Principle phases of the metastatic process. The first step of a metastatic event involves a phenotypical transformation, specifically epithelial-to-mesenchymal transition of tumor cells (EMT); this allows for tumor invasion into surrounding connective tissue. The hypoxic conditions of the tumor microenvironment will induce tumor cells to secrete angiogenetic factors, which promote the formation of new vessels for reaching nutrients (angiogenesis), and intravasation or entry into circulation. The circulating tumor cells will travel through the turbulent circulatory system until they arrive at distant organs; here, the cells interact with pre-formed pre-metastatic niches to form new cancerous growths. Eventually, these tumors can disseminate and form further distant metastases.

The survival of CTCs is not guaranteed in the circulation, nor is access to distant organs [107]. Indeed, less than $1 \%$ of circulating tumor cells (CTCs) promotes distant metastasis [103,107-109] due to the hostility of the bloodstream and the presence of immune cells [110].

Aggregated CTCs arrest at a distant microvascular bed and initiate the process of extravasation by secreting Angiopoietin-like 4 and metalloproteases to induce endothelial cell retraction and vascular hyperpermeability [111]. The developing micrometastasis initiates angiogenesis at the target site to allow the new tumor access to nutrients, often developing a clinically detectable large metastasis. These events require specific conditions in which EVs contribute (Figure 2). Here, we describe in detail how EVs regulate EMT, angiogenesis, immune escape, and pre-metastatic niches preparation, processes that are present in lung cancer metastasis. 


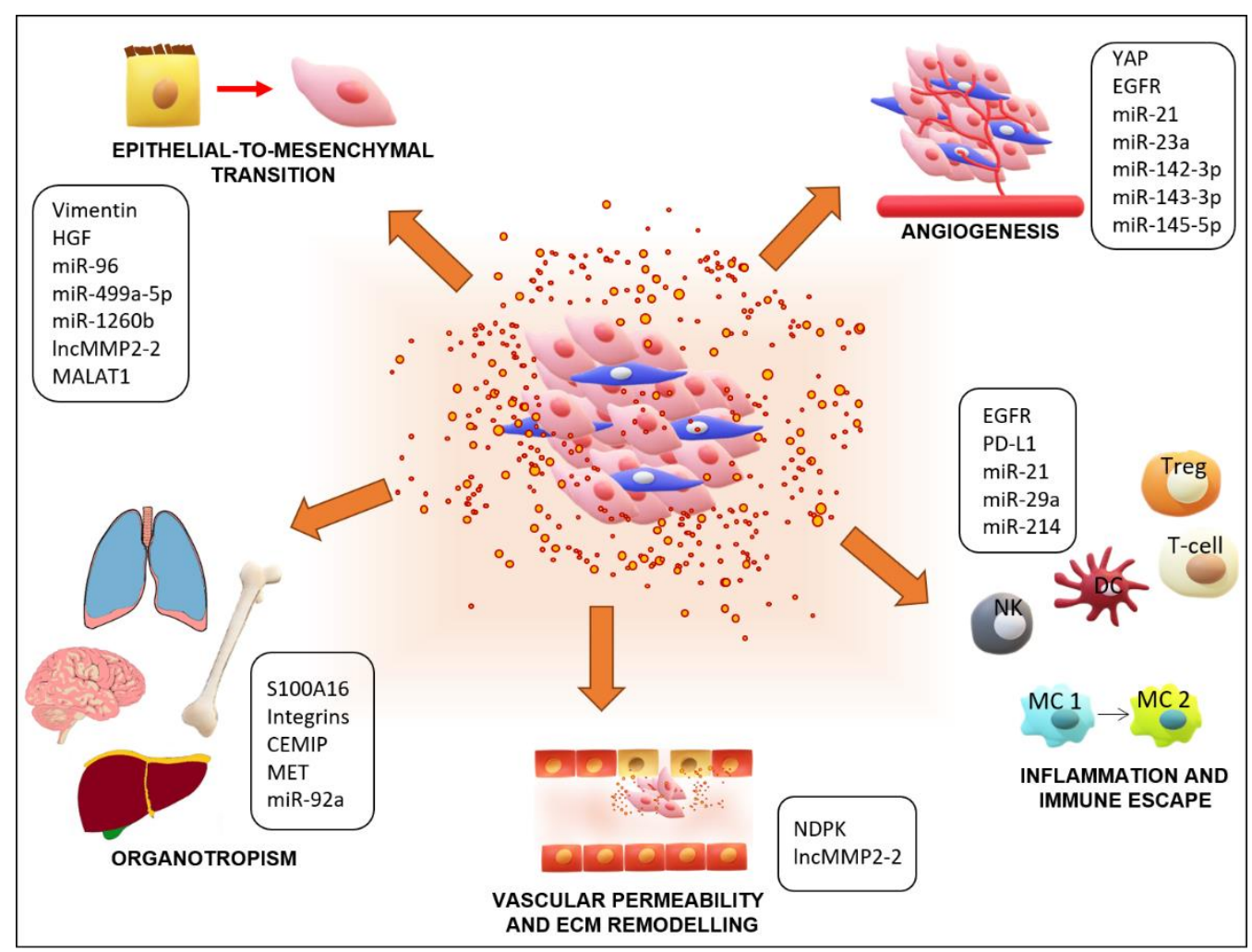

Figure 2. Role of extracellular vesicles (EVs) and their contents in promoting lung cancer metastasis. EVs derived from tumor cells, and other cells of the tumor microenvironment (TME), are involved in every step of the metastatic process of lung cancers. Proteins and RNAs contained in EVs can induce the first steps of metastasis, which are EMT and angiogenesis. Moreover, EVs are implicated in regulating inflammatory responses in the TME, in circulation, and at distant metastatic sites by activating $T$ regulatory cells (Treg), altering properties of dendritic cells (DC), inhibiting the activities of $\mathrm{T}$ cells and natural killer cells (NK), and inducing the polarization of macrophages (MC) from type 1 to type 2. At distant sites, EVs are involved in vascular permeability and organotropism by modifying the environment of pre-metastatic niches. Notable EV content that has been shown to contribute to lung cancer metastasis is highlighted for each process.

\subsection{EVs and EMT in Lung Cancer}

EMT is the first step for metastatic formation, and it contributes to the acquisition of invasive abilities of cancer cells. During this process, the cancer cells undergo a phenotypic change from epithelial to mesenchymal and occasionally acquire the characteristics of cancer stem cells, a rare subpopulation of tumor cells that are able to regenerate and differentiate [112-115]. From the morphological perspective, the cuboidal epithelial cells transition into a tapered shape, causing disruption in cell-cell junctions with degradation of adhesion proteins [116-118]. This conversion is marked by a shift in the expression of epithelial markers (E-cadherin, Zo-1, occludin) to mesenchymal markers (vimentin, N-cadherin, fibronectin) [119]. This shift is driven by altered gene expression regulation that impedes epithelial protein production and induces mesenchymal protein production $[120,121]$. The change in gene expression is indispensable for cytoskeleton reorganization and subsequent cell elongation and motility. Thus, cells evolve new actin-enriched membrane protrusions that facilitate movement, including lamellipodia, filopodia, and invadopodia [117,122]. These projections assist with a proteolytic activity that acts to degrade the extracellular matrix and allows for invasion [123]. In lung cancer, numerous signaling pathways, including Wnt/ $\beta$-catenin, TGF $\beta /$ Smad, IL-6/JAK/STAT3, and Notch-1, are involved in EMT $[119,124,125]$. These pathways lead to the activation of several transcription factors, such as SNAIL, zinc finger E-box binding homeobox 1 (ZEB1), FOXF2, and TWIST, which are responsible for the repression of endothelial markers and activation of mesenchymal 
genes $[121,126]$. The downregulation of these factors can prevent EMT. For example, miRNA-200 and the miRNA-183 96 182 cluster, which are significantly co-repressed in NSCLC, directly target FOXF2, blocking the mesenchymal phenotype [126]. Knockdown of E-cadherin has also been shown to induce a mesenchymal phenotype in A549 cells, which promotes their invasive ability through the activation of EGFR-MEK/ERK signaling. Subsequently, this pathway signaling induces the ZEB1-mediated increase of MMP2 expression and leads to acquired invasiveness [127].

In the last decade, researchers have started to propose a role for EVs as active attendees in the EMT process [128]. A growing body of evidence supports the notion that EVs contribute to the evolving tumor microenvironment (TME) [129-131]. In fact, cells secrete factors that can act as autocrine and / or paracrine signals to induce EMT and impact the TME $[132,133]$.

A recent miRNA profiling study reported the differential expression of several oncomiRNAs in an epithelial lung cancer cell line and its induced-mesenchymal phenotype [134]. Moreover, the exosomes derived from mesenchymal cells promoted migration, invasion, and expression of mesenchymal markers in epithelial cells [134]. MiRNA-499a-5p is upregulated in both highly metastatic lung cancer cell lines and their exosomes, and this upregulation induces proliferation, EMT, and migration. In addition, treatment with exosomes derived from highly metastatic cells confers migratory and proliferative properties to recipient lung cancer cells mediated through the mTOR pathway [135].

Exosomes isolated from lung adenocarcinoma patient serum exhibit enrichment of miRNA-1260b. Furthermore, the expression of this miRNA is higher in a lung cancer cell line harboring high invasive potential (H1299) compared to a less invasive cell line (A549) [136]. Treatment with miRNA-1260b-enriched exosomes isolated from H1299 cells is sufficient to increase the invasive ability of recipient A549 cells by inhibiting sFRP1 and Smad4. Mechanistically, the inhibition of sFRP1 and Smad4 activates the Wnt/ $\beta$-catenin pathway, which plays a critical role in the invasion and metastasis of lung cancer $[136,137]$. The Wnt/ $\beta$-catenin pathway interacts with many non-coding RNA upon osteogenic differentiation [138] and the importance of this pathway in lung cancer lies in its role in causing lung cancer metastasis to bones [139].

Exosomal miRNA-96 has been reported as a lung cancer biomarker and correlates with invasive properties of different lung cell lines. Less invasive A549 cells that were treated with miRNA-96-enriched exosomes released by the highly invasive cell line H1299 exhibited improved cell viability, migration, and cisplatin resistance through inhibition of LM07 [140].

Exosomal lncRNAs have also been implicated in EMT. Lung cancer cells treated with TGF $\beta$ exhibit increased EMT properties, and co-culture experiments with these cells induced vascular permeability in human lung microvascular endothelial cells (HMVEC-L). These effects were mediated by exosomal lncMMP2-2, which induces the expression of MMP2. Furthermore, the expression of lncMMP2-2 and MMP2 in lung cancer tissue correlated with tumor progression, which suggests a potential role as a prognostic biomarker or therapeutic target [141]. Zhang et al. demonstrated that lncRNA MALAT1 was highly expressed in NSCLC patients' serum, and its levels were associated with the tumor stage and metastasis [142]. In addition, exosomal MALAT1, derived from NSCLC patients, accelerates tumor migration and proliferation by suppressing apoptosis in lung cancer cell lines.

Protein cargo within exosomes, including vimentin, derived from a highly metastatic lung cancer cell line, was shown to drive EMT and induce proliferation, invasion, and migration in normal HBEC cells. Notably, similar results were obtained by treating HBECs with exosomes derived from the serum of late-stage lung cancer patients [143]. Another study showed that EVs released by highly metastatic cell lines contained an elevated level of HGF, and treatment with these EVs was shown to induce proliferation, invasion, and migration in low metastatic cells through the HGF/c-Met pathway [144]. 


\subsection{EVs and Angiogenesis}

Carcinoma cells require proximity to blood vessels in order to reach oxygen and nutrients directly. Without an adequate blood supply, tumor development and metastatic spread are hampered, with the tumor destined to become necrotic or apoptotic $[145,146]$. Angiogenesis is triggered by factors released by tumor cells during a phase of high growth $[106,147]$. Increased distance between the cells and the capillaries leads to a hypoxic state. To escape hypoxia-induced apoptosis, hypoxia-inducible factor $1 \alpha$ (HIF-1 $\alpha)$ is upregulated in the TME $[148,149]$. HIF- $1 \alpha$ is translocated into the nucleus, where it induces the expression of VEGF $[150,151]$.

Endothelial cells express the VEGF receptor (VEGFR), which once activated by the ligand, initiates a transduction cascade, leading to the production of matrix metalloproteases (MMP) [152,153]. Disruption of the matrix allows for more space for endothelial cells to divide and organize into a mature network of new vessels.

Numerous studies have reinforced the importance of the EV cargo as a tumor signaling factor, which assists in creating the appropriate microenvironment and further promoting angiogenesis [154-156]. Among the EV cargo, numerous proteins have been reported to be involved in angiogenesis. Among these proteins, high levels of yes-kinase-associated protein (YAP) have been found in non-small cell lung cancer (NSCLC) tissues compared to normal tissue [157], and its overexpression is associated with a poor prognosis [158]. The YAP contribution to proliferation and stem cell phenotype preservation has already been discovered, and it has also been described as a pro-angiogenetic factor in different types of tumors $[159,160]$. Recently, the EV-mediated transfer of YAP from lung adenocarcinoma was shown to promote angiogenesis in human umbilical vein endothelial cells (HUVECs) [157].

Further evidence of the involvement of the EV cargo in angiogenesis is based on the presence of EGFR in tumor-derived MVs. EGFR is commonly overexpressed during tumor vascularization [161-163]. Lung cancer cells have been shown to express and secrete EGFR through MVs. MV-mediated transport of activated EGFR not only allows for incorporation of the receptor into recipient endothelial cells but can also activate the MAPK and Akt pathways, inducing the expression of VEGF [164].

The Garnis group demonstrated that the tumor suppressors miRNA-143-3p and miRNA-145-5p $[165,166]$ were selectively packaged into EVs by lung adenocarcinoma cells [167]. EV-mediated transfer of miRNA-143-3p and miRNA-145-5p promoted tube formation by endothelial cells by targeting CAMK1D [167], an anti-angiogenic kinase. In a separate study, the same group showed that EV-encapsulated miRNA-142-3p was secreted by lung adenocarcinoma cells and transferred to endothelial cells, and promoted angiogenesis through inhibition of TGF $\beta$ R1 [168]. Exosomal lncRNAs are also involved in angiogenesis. Growth arrest-specific 5 (GAS5) inhibited HUVECs' proliferation and tube formation by increasing their apoptosis. Also, GAS5 was decreased in human lung cancer tissues, lung cancer cells, and in cell line-derived exosomes [169].

Under hypoxic conditions, investigators have demonstrated that miRNA-23a is released from lung cancer cells' EVs to induce angiogenic pathways in vitro and in vivo [170]. Transfer of miRNA-23a within EVs enhanced the proliferation and migration of HUVECs, two necessary steps for the angiogenic process. miRNA-23a is known to be oncogenic and is upregulated in several types of cancers and in hypoxic conditions [171,172]. MiRNA-23a targets the 3'UTR of PTEN mRNA [173], the protein of which interferes with the PI3K/AKT pathway, leading to the suppression of vascular formation [173,174]. PTEN downregulation is often associated with the upregulation of VEGFR2 in glioblastoma, underlying its role in angiogenesis suppression [175].

Exposure to cigarette smoke extract (CSE) has been shown to induce human bronchial epithelial cell (HBEC) transformation [176], with an increase in STAT3 and miRNA-21 expression compared to no CSE exposure. STAT3 is already known for its effect in EMT, in CSE exposed HBEC; its knockdown led to a decrease in miRNA-21 levels in EVs [177]. Moreover, miRNA-21 was efficiently transferred through exosome-mediated communi- 
cation from CSE-transformed HBE to HUVEC cells, which increases their angiogenic properties by activating VEGF. The importance of this discovery depends on the evidence that miRNA-21 was elevated in the serum of NSCLC patients and that the serum levels correlated with the smoke exposure [177]. Overall, this provides a new perspective for its employment as a potential therapeutic biomarker $[178,179]$.

\subsection{EVs and Immune Escape}

Tumor cells express distinct antigens that are recognized by dendritic cells and lymphocytes, thereby leading to their destruction [94]. Tumor cells can promote apoptosis of T cells and natural killer cells (NK) through the Fas/FasL and PD-1/PD-L1 pathways. Alternatively, they can release EVs that promote the formation of an immune-suppressive microenvironment [180]. Indeed, tumor-derived EVs can alter immune surveillance cells through functional activation, inhibition, or polarization of immune cells [180].

Functional activation refers to the expansion and activation of regulatory $\mathrm{T}$ (Treg) cells and myeloid-derived suppressor cells (MDSCs), which have immunosuppressive activities in TME, and further support self-tolerance by inhibiting T cell function [180,181]. Numerous studies have reported that tumor-released EVs induce the expansion and activity of these cells $[182,183]$.

It has been shown that exosomes from lung cancer tissues are enriched in EGFR, and that transfer of exosomes alters the properties of recipient dendritic cells (DCs), inducing tolerance and activation of Treg cells [184]. Yin et al. reported elevated expression of miRNA-214 in the tissue and plasma of patients with various cancers, including lung cancer. Tumor-secreted miR-214 can be delivered through MVs, leading to the expansion of Tregs by targeting PTEN in $\mathrm{CD}^{+} \mathrm{T}$ cells. Moreover, miRNA-214 promotes the secretion of IL-10 in Tregs, which encourages tumor growth in vivo [185].

Functional inhibition targets the silencing of normal antitumor responses that are mediated by DC, NK cells, and T-lymphocytes. CD8+ cytotoxic lymphocytes target tumor cells, and their dysfunction has been reported in many types of cancers [186-188]. The inhibition of CD8+ cells is mediated by the activation of checkpoint pathways such as PD1/PD-L1. Cancer cell surface expression of PD-L1 interacts with PD-1 on T cells, leading to their inhibition [189]. EVs may harbor and transfer PD-L1 to many cell types, including tumor cells, macrophages, and DC, thus contributing to the formation of an immunosuppressive microenvironment [180] EVs containing PD-L1 have been detected in the serum of patients with cancer [190-192]. Specifically, Li et al. found that the level of exosomal PD-L1 in NSCLC patients correlated with the tumor stage, size, number of positive lymph nodes, and presence of distant metastasis [192]. EVs secreted by tumor cells also harbor immunoinhibitory factors, such as Fas ligand and TNF-related apoptosis-inducing ligand, constraining the effect of antitumor immune cells and promoting their apoptosis [193,194].

The polarization of immune cells involves resident macrophages in the TME. M1type macrophages are proinflammatory, secreting interleukin-12 (IL-12), and promote the apoptosis of tumor cells. M2 macrophages secrete the anti-inflammatory interleukin-10 (IL-10), which supports tumor progression [195]. Tumor-associated macrophages mainly show an M2 phenotype, possibly resulting from the polarization of M1 macrophages to M2 macrophages [195-197]. Tumor-derived exosomes can deliver functional tyrosine kinase receptors and activate the MAPK pathway in monocytes, leading to the inhibition of apoptosis-related caspases [198]. In order to drive the formation of metastases, it is crucial that CTCs survive in the circulation. In the bloodstream, CTCs interact with circulating immune cells, including macrophages, NK, lymphocytes, neutrophils, Treg, monocytes, and DCs, which can then intercept and attack them before extravasation [199,200]. Mechanisms through which CTCs can escape from immune cells include the expression of PD-L1 and CD47 and the alteration of FAS/FASL, which can promote $\mathrm{T}$ cell apoptosis or protect tumor cells from apoptosis [199]. Ye et al. found that the number of CTCs in stage IV NSCLC patients negatively correlates with the number of NK cells and CD3+, CD4+, and CD4+/CD8+ lymphocytes, while a positive correlation was found with the number of Treg cells [201]. 


\subsection{Pre-Metastatic Niches and CTCs' Homing}

As previously discussed, metastases to specific organs tend to be tumor type-specific. In order to successfully seed distal organs, CTCs require an optimal environment; thus, the site of metastasis is manipulated and adapted to promote the attachment, survival, and outgrowth of CTCs [202].

The remodeling of pre-metastatic niches is a step-by-step process that includes: modifications in vascular permeability through upregulation of metalloproteases, angiogenesis, extracellular matrix remodeling, and alterations in immune cell accumulation $[100,182,203,204]$. Many factors contribute to this process, including those released from tumor cells and the recruitment of hematopoietic precursor cells and mesenchymal stem cells that allow for the engraftment of CTCs and their growth $[205,206]$. Proangiogenetic factors, such as VEGF-A and proinflammatory cytokines, including TNF $\alpha$ and TGF $\beta$, are released by cancer cells [205,207-209]. Cancer-associated fibroblasts modify the extracellular matrix by secreting metalloproteases and promoting the proliferation and invasion of tumor cells $[210,211]$. Hematopoietic precursor cells have been shown to express VEGFR and can colonize the pre-metastatic lung sites before the CTCs arrive [212,213]. In many tumor types, exosomes derived from cancer and non-cancer cells drive the generation and support of pre-metastatic sites upon CTCs' arrival [182,214-216]. It has been demonstrated that platelet-derived MVs induce proliferation and invasion in lung cancer cell lines and can stimulate the expression of MMP-9, VEGF, Il-8, and HGF in HUVEC cells [217]. Many types of cancer metastasize to the lungs after EVs have contributed to remodeling of the microenvironment. For example, nucleoside diphosphate kinase $\mathrm{A}$ and $B$ (NDPK)-enriched exosomes derived from breast cancer cells promote the migration of pulmonary vascular endothelial cells, improving their permeability [218]. In human renal carcinoma, MVs that are shed from a subpopulation of CD105+ cells induce angiogenesis and pre-metastatic niche formation. Treatment with these MVs enhanced lung metastases in immunocompromised severe combined immunodeficient (SCID) mice [219].

An interesting study by $\mathrm{Xu}$ et al. showed that human brain microvascular endothelial cells (HBMECs) promoted survival and apoptosis resistance in SCLC cell lines under stress conditions by releasing factors that modulate mitochondrial activity [220]. Elevated levels of S100A16, a member of the S100 family and a partner of the annexin family of proteins, were associated with brain metastasis. Co-culture with HBMECs led to the upregulation of S100A16 in SCLC cells, and this effect was suppressed by treatment with an inhibitor of exosome release, suggesting that HBMEC derived S100A16 contributes to SCLC metastasis to the brain. In a pivotal study, Peinado and colleagues elegantly demonstrated the effect of melanoma-derived exosomes on metastatic niche preparation. Labeled exosomes derived from highly metastatic B16-F10 cells were injected in naïve mice. Exosomes were then detected in specific target organs, including the lung, where they induced endothelial permeability and expression of genes related to extracellular matrix remodeling and inflammation (including heat-shock proteins, S100a8, and S100a9). In addition, a high number of bone marrow-derived cells were present at metastatic sites, and exosomal transfer of MET from melanoma cells to bone marrow progenitor cells promoted the metastatic effects [23].

In lung cancer, exosomal miRNA-21 and miRNA-29a bind and activate TLR8 and TLR7 in recipient immune cells, inducing the secretion of pro-metastatic cytokines through the activation of NF-kB [221]. In 2016, Liu and colleagues demonstrated that cancer-derived exosomes, enriched in small nuclear RNAs, activated TLR3 in lung epithelial cells, which induced the secretion of chemokines and promoted the formation of a pre-metastatic niche by recruiting neutrophils in the lung. Furthermore, they found a correlation between the level of TLR3 in adjacent tissue to lung cancer with the presence of neutrophils. Additionally, a reduction in overall survival was observed in lung cancer patients with high levels of both TLR3 and neutrophil infiltration [222].

Another critical study showed that the pattern of integrins contained in tumor-derived exosomes is implicated in organotropism and is responsible for organ-specific exosome 
uptake. Moreover, exosomal integrins can affect the expression of pro-metastatic genes through the activation of Src [223]. Further, the tetraspanin-8 is significantly enriched in EVs released by metastatic non-small cell lung cancer (NSCLC) cells when compared to a nonmetastatic cell line. NSCLC cell lines that were treated with EVs overexpressing tetraspanin8 displayed increased invasiveness [224]. Since the tetraspanin-integrin complex is essential for tumor-derived exosome recruitment at the pre-metastatic site, their involvement in the reprogramming of cells at these pre-metastatic niches can be speculated [225].

EVs containing miRNA-92a secreted by bone-marrow-derived cells can contribute to the establishment of a liver pre-metastatic niche in a lung cancer-bearing mice model [226]. Both bone-marrow-derived EVs and miRNA-92a increased hepatic stellate cell activation and expression of collagen type I, leading to the deposition of the extracellular matrix and inducing liver metastasis in vivo. Furthermore, elevated levels of miRNA-92a were found in lung cancer patients' serum [226].

The brain is a common site for metastasis in lung cancer, driving a poor prognosis and high mortality [227]. The brain is a hostile microenvironment for CTCs. However, tumor cell-derived exosomes may remodel this environment to support metastatic outgrowth, as recently demonstrated by Rodrigues et al. [228]. Analyses of the metastatic brain tumor led researchers to identify increased levels of cell migration-inducing and hyaluronan-binding protein (CEMIP) in the tumor compared to the surrounding stroma. Furthermore, the levels of CEMIP in primary tumors correlated with the presence of brain metastasis. Patients with high levels of CEMIP present in their brain metastasis had a poorer survival compared to patients with low levels. The uptake of CEMIP-enriched exosomes by brain endothelial cells and microglia led to an increase in proinflammatory cytokines, promoting metastasis. Interestingly, exosomes enriched in the CEMIP protein were also found in early-stage NSCLC primary tumors, with variable levels between patients, suggesting that it can serve as a potential biomarker for future brain metastasis [228].

These findings illustrate the importance of circulating EVs in pre-metastatic niche formation. Consequently, their use as biomarkers for early-stage cancer detection could reveal early disease progression. Therefore, to prevent metastasis formation, their potential as therapeutic targets should be urgently examined.

\section{Clinical Application of EVs}

Due to their unique physical characteristics (specific targeting, small size, and their ability to cross biological barriers), EVs have been increasingly examined in medical research, particularly in diagnosis and therapy, within the past several decades.

\subsection{Biomarkers in Lung Cancer}

Despite the advent of targeted therapies, immunotherapy, advances in minimally invasive surgery, and supportive care, the prognosis for lung cancer remains poor, with a five-year survival of 19\% [26]. Biomarkers that can assist clinicians with an early diagnosis are essential to improving prognosis. Furthermore, clinically informative biomarkers may assist in predicting therapeutic responses. In the past several years, EVs and their contents have emerged as a potential source for developing novel non-invasive biomarkers. Most EV components (membrane proteins, lipids, and cargo nucleic acids) have been investigated as biomarkers. Hurwitz et al. demonstrated differentially expressed proteins in EVs extracted from 60 different cancer cell lines (NCI-60 that includes nine lung cell lines), indicating that EV contents have cancer specificity [229]. A study of 49 exosomal membrane proteins in 276 patients reported that NY-ESO-1 might be a reliable prognostic biomarker in NSCLC [230]. Furthermore, exosomal EGFR expression levels were found to be elevated in five out of nine cancer cases compared to healthy controls. In contrast, in the same patients, the soluble EGFR levels in plasma were distinguishable between the cancer and control patients [230]. In 2018, Wang et al. analyzed lipopolysaccharide-binding proteins (LBP) in the exosomal membrane and determined that it could distinguish between metastatic and non-metastatic NSCLC [231]. Additionally, CD171, CD151, and tetraspanin-8 (Tspan8) could 
also be differentiated for lung cancer patients, both NSCLC and SCLC, compared to controls [232]. As previously described, Liu et al. found an upregulation of Tspan8 in metastatic cell line-derived EVs. They also found an elevated expression of Tspan8 in serum EVs of individuals with stage III NSCLC tumors and reduced distant metastasis-free survival [224].

RNAs within EVs are also potential cancer biomarkers [233]. Exosomal nucleic acids (exoNAs) from NSCLC patient plasma for common BRAF, KRAS, and EGFR mutations showed higher sensitivity for assessing clinical outcomes as compared to plasma ctDNA [234]. Hur et al. analyzed EV-derived plasma DNA plasma and bronchoalveolar lavage fluid (BALF) from NSCLC patients. They discovered higher concordance with a conventional tissue biopsy compared to circulating free DNA (cfDNA). In addition, the EGFR p.T790M mutation was detectable in patients developing EGFR-TKI resistance [235].

Numerous studies have described cargo ncRNAs as biomarkers in lung cancer [236] (Table 2).

Table 2. Principal dysregulated non-coding RNAs and their clinical applications in lung cancer.

\begin{tabular}{|c|c|c|c|}
\hline Function & Non-Coding RNA & Clinical Applications & Reference \\
\hline \multirow{7}{*}{ EMT } & miRNA-200 family & Predictive, diagnostic & {$[126,237-239]$} \\
\hline & miRNA-183 96 182 cluster & Diagnostic & {$[126,240]$} \\
\hline & miRNA-499a-5p & & [135] \\
\hline & miRNA-1260b & Biomarker & [136] \\
\hline & miRNA-96 & Biomarker & [140] \\
\hline & lncMMP2-2 & Prognostic & [141] \\
\hline & MALAT1 & Prognostic & [142] \\
\hline \multirow{5}{*}{ Angiogenesis } & miRNA $143-3 p$ & Biomarker & [167] \\
\hline & miRNA $145-5 p$ & Biomarker & [167] \\
\hline & miRNA $142-3 p$ & & [168] \\
\hline & GAS5 & Biomarker & [169] \\
\hline & miRNA-23a & Biomarker of disease & [171] \\
\hline \multirow{4}{*}{ Immune escape } & miRNA-214 & Biomarker & [185] \\
\hline & miRNA-21 & Predictive, diagnostic, prognostic & {$[221,236,241-248]$} \\
\hline & $\operatorname{miR}-29 a$ & & [221] \\
\hline & miRNA-92a & Biomarker & [226] \\
\hline \multirow{15}{*}{ Biomarker } & miRNA-10b-5p & Prognostic, survival & [236] \\
\hline & miRNA-23b-3p & Prognostic, diagnostic, survival & {$[236,249]$} \\
\hline & miRNA-139-5p & Screening & [237] \\
\hline & miRNA-378a & Screening & [237] \\
\hline & miRNA-379 & Screening & [237] \\
\hline & miRNA-4257 & Predictive & [241] \\
\hline & miRNA-122 & Predictive, therapeutic & {$[250,251]$} \\
\hline & miRNA-205 & Predictive, diagnostic & {$[250,252]$} \\
\hline & miRNA-126 & Diagnostic & {$[250,253]$} \\
\hline & miRNA-16 & Prognostic & {$[250,254]$} \\
\hline & Let-7 & Prognostic & {$[250,255]$} \\
\hline & HAGLR & Prognostic & [256] \\
\hline & miRNA-1-3p & Diagnostic & [257] \\
\hline & miRNA-144-5p & Diagnostic & [257] \\
\hline & miRNA-150-5p & Diagnostic & [257] \\
\hline \multirow{2}{*}{ Drug resistance } & lncRNA RP11-838N2.4 & Erlotinib resistance & [258] \\
\hline & lncRNA H19 & Gefitinib resistance & [259] \\
\hline
\end{tabular}


In particular, miRNAs including miRNA-21 [241,243,260], miRNA-23b-3p, miR-10b5p [249,261], miRNA-139-5p miRNA-200b-5p, miRNA-378a, miRNA-379, and miRNA-4257 were found to be dysregulated in EVs of lung cancer patients compared to healthy controls $[237,241,249,261,262]$. Circulating miRNAs can be used as predictive (e.g., miRNA-21, miRNA-122, and miRNA-205), diagnostic (e.g., miRNA-21, miRNA-126, and miRNA-205), and prognostic (e.g., miRNA-21, miRNA-16, and let-7) biomarkers for lung cancer [250]. A recent meta-analysis suggested that EV-derived lncRNA MALAT1 could be a promising biomarker for NSCLC screening; however, due to its low specificity, further validation is required [263]. Zang et al. describe a positive correlation of MALAT-1 levels in serum-derived exosomes with the tumor stage and lymphatic metastasis [142]. LncRNA growth arrestspecific transcript 5 (GAS5) was downregulated in patients with NSCLC. This lncRNA was inversely expressed to the tumor stage [264]. In 2019, Rao et al. showed that exosome lncRNA HAGLR and CTCs could serve as biomarkers in NSCLC patients [256].

EV lncRNAs have also been implicated in drug resistance. For example, in NSCLC, lncRNA RP11-838N2.4 was linked to erlotinib resistance [258], while lncRNA H19 was linked to gefitinib resistance [259].

Recently, investigators have examined post-transcriptional RNA modifications (reviewed in [265-267]) as diagnostic biomarkers. In a recent paper, Nigita et al. identified first-time differences in the editing level of mature miRNAs in circulating exosomes of NSCLC patients [268,269].

Promising biomarkers have also been reported in other body fluids. In urine, leucinerich alpha-2-glycoprotein 1 (LRG1) was upregulated in tissue and urinary exosomes from NSCLC patients [270]. Sun et al. profiled salivary EVs in healthy and lung cancer patients and described four proteins (BPIFA1, CRNN, MUC5B, and IQGAP) as potential biomarker candidates in lung cancer [271]. miRNA-1-3p, miRNA-144-5p, and miRNA-150-5p were also identified in pleural lavage [257]. A comparison between EVs from pleural fluid of lung cancer, pulmonary tuberculosis, or pneumonia patients demonstrated differential miRNA expression patterns [272].

Indeed, the combination of more than one biomarker increases the accuracy. For example, combining EVs RNA and ctDNA increased the sensitivity of EGFR mutation detection in NSCLC patients' plasma [273]. Despite these exciting advances, the translation of exosome-based technologies to clinical application still requires standardized methods for isolating EVs and must take into consideration the heterogeneity of cancer-derived EVs and their immunological effects [182,274-276].

\subsection{Therapeutic Targets}

Given the crucial role of EVs in cancer progression and the metastatic process, many studies have focused on the use of EVs as therapeutic targets through inhibition of EV formation in tumor donation cells, inhibition of EV uptake in recipient cells, and the ablation of circulating EVs.

Key molecules in EV biogenesis and secretion are considered potential candidates for EV-targeting treatment and include neutral sphingomyelinase 2 (nSMase2) and the Rab family (Rab22, Rab7a, Rab27a, Rab27b, Rab11, etc.). nSMase2 is known to regulate EVs' production, and its targeting can reduce tumor growth and distant metastasis [155,277]. This protein regulates EV-associated miR-210 secretion and promotes angiogenesis, therefore, affecting the capacity for metastasis in breast cancer [155]. Yokoi et al. used an ovarian cancer orthotopic mouse model derived from an nSMase2 KD (knockdown) cell line and observed a significant reduction in metastases to the peritoneal cavity [278]. Fabbri et al. used GW4869, a nSMase2 inhibitor, and observed a decrease in pulmonary metastasis in mice with lung cancer [221]. Inhibition of nSMase in PC-3 prostate cancer cells did not affect EV release, suggesting that EV biogenesis regulation may be cancer-specific [279].

Targeting Rab proteins is another strategy to downregulate EV release in cancer. In lung cancer cells (A549), EV release was significantly downregulated following targeted inhibition of Rab27a and Rab32 [280,281]. Inhibition of Rab27a led to a reduction in 
primary tumor growth and the number of lung metastases in a $4 \mathrm{~T} 1$ cell (metastatic cell line) xenograft but not in a TS/A (non-metastatic) xenograft model, indicating a possible therapeutic use of Rab27 inhibition for reducing metastases [282]. The inhibition of Rab37 reduced lung cancer stemness in vitro and in vivo [283].

The use of dimethyl amiloride (DMA), a Ca2+ blocker used in cardiology, has shown an inhibitory effect on EV release in vitro (colon, lung, and lymphoma cell lines) [284] and in vivo [285]. The in vivo studies indicated that DMA enhances the antitumor efficacy of cyclophosphamide, suggesting it should be considered as part of combination therapy for cancer [285]. In glioblastoma, heparin (a heparan sulfate inhibitor) inhibited EV uptake and downregulated cell migration [88]. Dynasore, a clathrin-mediated endocytosis pathway inhibitor, caused a significant decrease in EV uptake in lymphoma [286] and normal endothelial cells [287].

In PC9 cells, a NSCLC cell line, EVs extracted following gefitinib treatment reduced cisplatin's antitumor effect, which is associated with an increase in autophagy. The authors demonstrate an antagonistic effect of gefitinib and cisplatin due to gefinitib-stimulated EVs. They suggested a washout period to completely eliminate TKI-related exosomes before the next cycle of chemotherapy [288].

Targeting EV release/uptake machinery has two main challenges: (1) EV release/uptake pathways remain poorly understood, and (2) There is a lack of methods for selective EV inhibition. Since EVs are involved in normal physiological communication, therapies should be as tumor-specific as possible to minimize disruption to the natural homeostatic function of EVs. Improvement in understanding and targeting tumor-selected pathways, as well as tumor-specific markers on the EV surface and EV cargo, will be essential to successful targeting.

\subsection{EVs as Vehicles for Therapy}

EVs have been considered an ideal vehicle for therapeutic agent delivery (drug/nucleic acid) [269]. In particular, their stability in physiological and pathological conditions and decreased immunogenicity compared to other nanocarriers are two attractive features. EVs can selectively deliver their cargo based on the presence of specific membrane proteins [289]. In 2015, Hoshino et al. describe an association between exosomal integrins and preferential tissue metastasis: the presence of $\alpha_{6} \beta_{4}$ and $\alpha_{6} \beta_{1}$ was associated with lung metastases, while exosomal integrin $\alpha_{\mathrm{v}} \beta_{5}$ was linked to liver metastases [223]. $\alpha 2,3$-linked sialic acid on exosomes is linked to spleen-specific delivery [290]. CD63 ${ }^{+}$EVs target neuronal and glial cells. Furthermore, CD63- ${ }^{-}$selectively targets dendritic cells [291], while the Tspan8/integrin a4 complex selectively targets EVs to pancreatic cells [292].

Before using EVs as a delivery system, it is crucial to evaluate the EV biodistribution, lifetime, circulation kinetics, and overall pharmacokinetics. EVs accumulate preferentially in the liver, spleen, kidney, and gastrointestinal system [293]. EV biodistribution is determined by the targeting, cell source, and route of administration [294,295]. Wiklander et al. reported that EV membrane proteins are essential for biodistribution [295]. This is supported by evidence showing that proteinase $\mathrm{K}$ treatment of EVs prior to intravenous injection in mice significantly reduced lung distribution. Interestingly, proteinase K treatment did not affect macrophage uptake [296]. CD47 is a "don't eat me" signal present on the membrane of many tumor cells and EVs; thus, it can protect cells and EVs from phagocytosis by monocytes and macrophages [297-299]. Studies on the structure, functions, and uses of CD47-inhibition assess the potential and challenges of the CD47-SIRP $\alpha$ signaling pathway in anticancer therapy [300]. Engineered EVs for therapy can utilize CD47 to increase the lifetime of EVs [298]. Furthermore, by using a function-blocking CD47 antibody, it is possible to modulate multiple EV-mediated signals between breast carcinoma cells and endothelial cells that are important for supporting tumor growth and metastasis [301]. On the other hand, using exosome-SIRPa, which is the ligand of CD47, is sufficient to increase the tumor cell phagocytosis and prime an antitumor T cell response [302]. Another method to improve the circulation time and biodistribution of 
EVs is by coating the EVs with polyethylene-glycol (PEG) conjugated with anti-EGFR nanobodies or with streptavidin [303,304].

Different types of cells are under investigation as potential sources of EVs as vehicles for drug delivery. Dendritic cells (DCs), as APCs, were used as cancer immunotherapy, but their use in clinical practice has bene found to be challenging [305,306]. Dendritic cell-derived exosomes (DEXs) have been studied as an alternative to DCs as anticancer vaccines, given their ability to activate the immune response. A few clinical trials, both phase I and phase II, demonstrate that DEXs can initiate the adaptative and innate immune system, encouraging the future use of this strategy for cancer treatment, including for NSCLC, melanoma, and colorectal cancer [307]. Currently, a phase II clinical trial is evaluating the use of antigen-loaded dendritic cell-derived exosomes as a vaccine in NSCLC (http:/ / clinicaltrials.gov NCT01159288 (accessed on 1 November 2021). Furthermore, many in vitro and in vivo studies demonstrate that DEX can also serve as an effective drug delivery system [307-311]. Mesenchymal stem cells (MSCs) possess anti-inflammatory and strong regenerative effects [312]. They have therapeutic potential against various diseases, such as cardiovascular disease, liver injury, renal injury, and neural injury [313]. Furthermore, MSC-derived exosomes (MEVs) largely contribute to MSCs' therapeutic effects $[314,315]$. There is an ongoing investigation seeking to improve MEV-based drug delivery systems for clinical use in different diseases, including cancer [316-319].

Macrophage-derived EVs have also been considered for immunotherapy, given their ability to activate the T cell response and act as a drug delivery system [310]. Aminoethyl anisamidepolyethylene glycol (AA-PEG) exosomes that are loaded with paclitaxel accumulated in high concentrations in cancer cells and improved therapeutic outcomes on lung metastases [320]. EVs from tumor cells (TEVs), and in particular, autologous TEVs, have been used for therapeutic purposes. In a recent paper, Guo and colleagues evaluated the therapeutic potential of TEVs in the context of malignant pleural effusion (MPE) [321]. The authors obtained robust results when assessing the safety, immunogenicity, and clinical activity of autologous TEVs-patching methotrexate [321]. Recently, a TEVs-based platform for anti-miR-21 delivery and magnetic resonance imaging (MRI) has been investigated in breast cancer [322]. The study demonstrated that TEV-mediated anti-miR-21 delivery reduced doxorubicin (DOX) resistance in breast cancer cell lines; the authors also demonstrated a tumor-specific accumulation of TEV using MRI. This paves the way for the use of TEVs for future applications in cancer molecular imaging and therapy [322]. Finally, in the last five years, milk and red blood cells (RBCs) have been considered a good source of EVs for therapy due to their abundance and cost-effective benefits [310].

One of the primary challenges of EV-mediated delivery is the lack of target specificity. The "perfect" carrier must be stable but also target cell or organ type-specific. Lysosomeassociated membrane protein 2 (Lamp2b) is one of the most used anchor proteins for coupling target peptides or antibodies to enhance EV targeting [323]. Lamp2b anchored with rabies viral protein (RGV), a protein that binds acetylcholine receptors, can selectively target neurons and microglia [324]; if anchored with muscle-specific peptide, they can also selectively target $\mathrm{C} 2 \mathrm{C} 12$ muscle cells [324]. Lamp2b with cardiomyocyte-specific peptide (CMP) or cardiac targeting peptide (CTP) can result in increased EV uptake by cardiomyocytes in vivo [325,326].

EVs expressing membrane glycosylphosphatidylinositol (GPI) fused with anti-EGFR nanobodies target tumor cells with even more specificity [327]. Also, EVs with plateletderived growth factor receptors fused to the GE11 peptide (EGFR specific) on their surface can specifically target EGFR-expressing xenografts in breast cancer [328]. Nucleic acid aptamers that can recognize specific target molecules are used to increase the specificity of targeting the PSMA aptamer in prostate cancer xenografts, EGFR aptamer in breast cancer xenografts, and survivin in colorectal cancer xenografts [329]. In another study, aptamers against nucleolin were used to target breast cancer cells that express an upregulation of this membrane protein. This resulted in an inhibition of tumor growth in vivo [330]. Qi 
and colleagues successfully used transferrin-conjugated super-magnetic nanoparticles to control and target murine tumors using external magnets [331].

Lastly, it is essential to consider the EV cargo and how the cargo can be packaged within vesicles. There are two approaches for EV loading: exogenous (i.e., after EV isolation) and endogenous (i.e., during EV biogenesis). Often, the best strategy is dependent on the source of the EVs and the cargo to load (reviewed in [35,332,333]).

The primary EV cargos used for therapy are nucleic acid and drugs. There are many preclinical studies and a few clinical trials that demonstrate the efficiency of EVs in many diseases. EVs that selectively deliver miRNA or siRNA to enhance the drug sensitivity, or use EVs to selectively direct drugs in tumor cells, have been of particular interest.

TRAIL-expressing EVs derived from MSCs induced apoptosis in 11 resistant and sensitive cancer lines (including three lung cancer lines, four malignant pleural mesothelioma lines, two renal cancer lines, one human breast adenocarcinoma line, and one neuroblastoma line) in a dose-dependent manner while showing no cytotoxicity in primary human bronchial epithelial cells [334].

MSC EVs overexpressing miR-122 were used to downregulate domain-containing protein 10 (ADAM10), insulin-like growth factor 1 receptor (IGF1R), and cyclin G1 (CCNG1), three proteins implicated in hepatocellular carcinoma. This downregulation enhanced the therapeutic effects of TKI sorafenib in a preclinical hepatocellular carcinoma ectopic tumor model [335]. Mendt and colleagues demonstrated that engineered EVs with siRNA or shRNA molecules targeting KRASG12D induced apoptosis of pancreatic cancer cells and increased the survival of mice harboring advanced KPC689 pancreatic tumor cells [336]. These engineered EVs (iExosome) are in an ongoing clinical trial (NCT03608631).

There remain a few concerns for the future of EVs in cancer therapy. One of the most relevant issues is the lack of standardized techniques for the isolation and purification of exosomes. In fact, one of the most active current fields of research on EVs is developing an efficient and precise method of exosome isolation [337]. Secondly, it is essential to determine the EV source. For example, tumor cell-derived EVs can contain oncogenic markers that may contribute to cancer progression. Furthermore, there is limited drug loading efficiency, which can be due to limited space (EVs contain their parent cell line contents) [338]. The ongoing search for new methods to increase drug-drug loading and $\mathrm{EVs}^{\prime}$ yield is ongoing. Yang et al. were able to increase by up to 50-fold the exosome numbers and by more than 103-fold the exosomal cargo. This was accomplished using cellular-nanoporation [339]. Until recently, there has been no method for sufficient clinicalgrade production [310]. Before EVs can be considered a reliable therapeutic platform, we must develop an efficient, reproducible, and cost-effective production method on a large scale.

\section{Conclusions}

The contributions of EVs to understanding the metastatic processes at the diagnostic and therapeutic levels have become increasingly evident in a short period. Although the role of EVs in the hallmarks of cancer continues to evolve, it is important to remain cognizant of the inherent limitations that remain associated with isolating EVs and characterizing their contents. EVs are involved in several important processes that lead to the establishment of distant metastases, making them suitable targets for cancer therapies. However, challenges with targeting cancer-specific EVs can be attributed to our limited knowledge when it comes to targeting EVs that are uniquely released by cancer cells. Fortunately, the characteristics that define EVs as excellent carriers can be utilized to create vesicles for targeted drug molecule delivery. Furthermore, the diversity and uniqueness of EV content provide researchers with valuable sources from which to discover new cancer-specific biomarkers.

Author Contributions: Writing—original draft preparation, M.S. and G.R.; writing—review and editing, M.S., G.R., P.L., M.A. and P.N.-S.; supervision, M.S., G.R. and P.N.-S.; funding acquisition, M.A. and P.N.-S. All authors have read and agreed to the published version of the manuscript. 
Funding: This work was supported by the National Institutes of Health Grants: NCI 5U01CA213330, 1P20CA252717-01A1, and NCATS 5KL2TR002648.

Conflicts of Interest: The authors declare no conflict of interest.

\section{References}

1. Raposo, G.; Stoorvogel, W. Extracellular vesicles: Exosomes, microvesicles, and friends. J. Cell Biol. 2013, 200, 373-383. [CrossRef]

2. Colombo, M.; Raposo, G.; Thery, C. Biogenesis, secretion, and intercellular interactions of exosomes and other extracellular vesicles. Annu. Rev. Cell Dev. Biol. 2014, 30, 255-289. [CrossRef]

3. Admyre, C.; Johansson, S.M.; Qazi, K.R.; Filen, J.J.; Lahesmaa, R.; Norman, M.; Neve, E.P.; Scheynius, A.; Gabrielsson, S. Exosomes with immune modulatory features are present in human breast milk. J. Immunol. 2007, 179, 1969-1978. [CrossRef]

4. Caby, M.P.; Lankar, D.; Vincendeau-Scherrer, C.; Raposo, G.; Bonnerot, C. Exosomal-like vesicles are present in human blood plasma. Int. Immunol. 2005, 17, 879-887. [CrossRef] [PubMed]

5. Ogawa, Y.; Miura, Y.; Harazono, A.; Kanai-Azuma, M.; Akimoto, Y.; Kawakami, H.; Yamaguchi, T.; Toda, T.; Endo, T.; Tsubuki, M.; et al. Proteomic analysis of two types of exosomes in human whole saliva. Biol. Pharm. Bull. 2011, 34, 13-23. [CrossRef] [PubMed]

6. Pisitkun, T.; Shen, R.F.; Knepper, M.A. Identification and proteomic profiling of exosomes in human urine. Proc. Natl. Acad. Sci. USA 2004, 101, 13368-13373. [CrossRef] [PubMed]

7. Admyre, C.; Grunewald, J.; Thyberg, J.; Gripenback, S.; Tornling, G.; Eklund, A.; Scheynius, A.; Gabrielsson, S. Exosomes with major histocompatibility complex class II and co-stimulatory molecules are present in human BAL fluid. Eur. Respir. J. 2003, 22, 578-583. [CrossRef]

8. Chiasserini, D.; van Weering, J.R.; Piersma, S.R.; Pham, T.V.; Malekzadeh, A.; Teunissen, C.E.; de Wit, H.; Jimenez, C.R. Proteomic analysis of cerebrospinal fluid extracellular vesicles: A comprehensive dataset. J. Proteom. 2014, 106, 191-204. [CrossRef]

9. Clayton, A.; Mitchell, J.P.; Court, J.; Mason, M.D.; Tabi, Z. Human tumor-derived exosomes selectively impair lymphocyte responses to interleukin-2. Cancer Res. 2007, 67, 7458-7466. [CrossRef]

10. Clayton, A.; Mitchell, J.P.; Court, J.; Linnane, S.; Mason, M.D.; Tabi, Z. Human tumor-derived exosomes down-modulate NKG2D expression. J. Immunol. 2008, 180, 7249-7258. [CrossRef]

11. Liu, C.; Yu, S.; Zinn, K.; Wang, J.; Zhang, L.; Jia, Y.; Kappes, J.C.; Barnes, S.; Kimberly, R.P.; Grizzle, W.E.; et al. Murine mammary carcinoma exosomes promote tumor growth by suppression of NK cell function. J. Immunol. 2006, 176, 1375-1385. [CrossRef]

12. Yu, S.; Liu, C.; Su, K.; Wang, J.; Liu, Y.; Zhang, L.; Li, C.; Cong, Y.; Kimberly, R.; Grizzle, W.E.; et al. Tumor exosomes inhibit differentiation of bone marrow dendritic cells. J. Immunol. 2007, 178, 6867-6875. [CrossRef] [PubMed]

13. Eken, C.; Gasser, O.; Zenhaeusern, G.; Oehri, I.; Hess, C.; Schifferli, J.A. Polymorphonuclear neutrophil-derived ectosomes interfere with the maturation of monocyte-derived dendritic cells. J. Immunol. 2008, 180, 817-824. [CrossRef] [PubMed]

14. Baj-Krzyworzeka, M.; Majka, M.; Pratico, D.; Ratajczak, J.; Vilaire, G.; Kijowski, J.; Reca, R.; Janowska-Wieczorek, A.; Ratajczak, M.Z. Platelet-derived microparticles stimulate proliferation, survival, adhesion, and chemotaxis of hematopoietic cells. Exp. Hematol. 2002, 30, 450-459. [CrossRef]

15. Baj-Krzyworzeka, M.; Szatanek, R.; Weglarczyk, K.; Baran, J.; Zembala, M. Tumour-derived microvesicles modulate biological activity of human monocytes. Immunol. Lett. 2007, 113, 76-82. [CrossRef] [PubMed]

16. Sprague, D.L.; Elzey, B.D.; Crist, S.A.; Waldschmidt, T.J.; Jensen, R.J.; Ratliff, T.L. Platelet-mediated modulation of adaptive immunity: Unique delivery of CD154 signal by platelet-derived membrane vesicles. Blood 2008, 111, 5028-5036. [CrossRef]

17. Simhadri, V.R.; Reiners, K.S.; Hansen, H.P.; Topolar, D.; Simhadri, V.L.; Nohroudi, K.; Kufer, T.A.; Engert, A.; Pogge von Strandmann, E. Dendritic cells release HLA-B-associated transcript-3 positive exosomes to regulate natural killer function. PLoS ONE 2008, 3, e3377. [CrossRef]

18. Chivet, M.; Hemming, F.; Pernet-Gallay, K.; Fraboulet, S.; Sadoul, R. Emerging role of neuronal exosomes in the central nervous system. Front. Physiol. 2012, 3, 145. [CrossRef]

19. Andaloussi, S.E.; Mager, I.; Breakefield, X.O.; Wood, M.J. Extracellular vesicles: Biology and emerging therapeutic opportunities. Nat. Rev. Drug Discov. 2013, 12, 347-357. [CrossRef]

20. Lai, R.C.; Arslan, F.; Lee, M.M.; Sze, N.S.; Choo, A.; Chen, T.S.; Salto-Tellez, M.; Timmers, L.; Lee, C.N.; El Oakley, R.M.; et al. Exosome secreted by MSC reduces myocardial ischemia/reperfusion injury. Stem Cell Res. 2010, 4, 214-222. [CrossRef]

21. Zhang, W.; Ou, X.; Wu, X. Proteomics profiling of plasma exosomes in epithelial ovarian cancer: A potential role in the coagulation cascade, diagnosis and prognosis. Int. J. Oncol. 2019, 54, 1719-1733. [CrossRef] [PubMed]

22. Rak, J.; Guha, A. Extracellular vesicles-Vehicles that spread cancer genes. Bioessays 2012, 34, 489-497. [CrossRef] [PubMed]

23. Peinado, H.; Aleckovic, M.; Lavotshkin, S.; Matei, I.; Costa-Silva, B.; Moreno-Bueno, G.; Hergueta-Redondo, M.; Williams, C.; Garcia-Santos, G.; Ghajar, C.; et al. Melanoma exosomes educate bone marrow progenitor cells toward a pro-metastatic phenotype through MET. Nat. Med. 2012, 18, 883-891. [CrossRef]

24. Becker, A.; Thakur, B.K.; Weiss, J.M.; Kim, H.S.; Peinado, H.; Lyden, D. Extracellular Vesicles in Cancer: Cell-to-Cell Mediators of Metastasis. Cancer Cell 2016, 30, 836-848. [CrossRef] [PubMed]

25. Planchard, D.; Popat, S.; Kerr, K.; Novello, S.; Smit, E.F.; Faivre-Finn, C.; Mok, T.S.; Reck, M.; Van Schil, P.E.; Hellmann, M.D.; et al. Metastatic non-small cell lung cancer: ESMO Clinical Practice Guidelines for diagnosis, treatment and follow-up. Ann. Oncol. 2018, 29 (Suppl. 4), iv192-iv237. [CrossRef] 
26. Siegel, R.L.; Miller, K.D.; Fuchs, H.E.; Jemal, A. Cancer Statistics, 2021. CA Cancer J. Clin. 2021, 71, 7-33. [CrossRef]

27. Howlader, N.; Forjaz, G.; Mooradian, M.J.; Meza, R.; Kong, C.Y.; Cronin, K.A.; Mariotto, A.B.; Lowy, D.R.; Feuer, E.J. The Effect of Advances in Lung-Cancer Treatment on Population Mortality. N. Engl. J. Med. 2020, 383, 640-649. [CrossRef] [PubMed]

28. Swanton, C.; Govindan, R. Clinical Implications of Genomic Discoveries in Lung Cancer. N. Engl. J. Med. 2016, 374, 1864-1873. [CrossRef] [PubMed]

29. Paez, R.; Kammer, M.N.; Massion, P. Risk stratification of indeterminate pulmonary nodules. Curr. Opin. Pulm. Med. 2021, 27, 240-248. [CrossRef]

30. Smith, H.B.; Ward, R.; Frazier, C.; Angotti, J.; Tanner, N.T. Guideline-Recommended Lung Cancer Screening Adherence Is Superior with a Centralized Approach. Chest 2021, in press. [CrossRef]

31. Schabath, M.B.; Cote, M.L. Cancer Progress and Priorities: Lung Cancer. Cancer Epidemiol. Biomark. Prev. 2019, 28, 1563-1579. [CrossRef]

32. Riihimaki, M.; Hemminki, A.; Fallah, M.; Thomsen, H.; Sundquist, K.; Sundquist, J.; Hemminki, K. Metastatic sites and survival in lung cancer. Lung Cancer 2014, 86, 78-84. [CrossRef]

33. Xu, R.; Rai, A.; Chen, M.; Suwakulsiri, W.; Greening, D.W.; Simpson, R.J. Extracellular vesicles in cancer-Implications for future improvements in cancer care. Nat. Rev. Clin. Oncol. 2018, 15, 617-638. [CrossRef] [PubMed]

34. Chargaff, E.; West, R. The biological significance of the thromboplastic protein of blood. J. Biol. Chem. 1946, 166, 189-197. [CrossRef]

35. Srivastava, A.; Amreddy, N.; Pareek, V.; Chinnappan, M.; Ahmed, R.; Mehta, M.; Razaq, M.; Munshi, A.; Ramesh, R. Progress in extracellular vesicle biology and their application in cancer medicine. Wiley Interdiscip. Rev. Nanomed. Nanobiotechnol. 2020, 12, e1621. [CrossRef] [PubMed]

36. Valadi, H.; Ekstrom, K.; Bossios, A.; Sjostrand, M.; Lee, J.J.; Lotvall, J.O. Exosome-mediated transfer of mRNAs and microRNAs is a novel mechanism of genetic exchange between cells. Nat. Cell Biol. 2007, 9, 654-659. [CrossRef] [PubMed]

37. Juan, T.; Furthauer, M. Biogenesis and function of ESCRT-dependent extracellular vesicles. Semin. Cell Dev. Biol. 2018, 74, 66-77. [CrossRef]

38. Raiborg, C.; Stenmark, H. The ESCRT machinery in endosomal sorting of ubiquitylated membrane proteins. Nature 2009, 458, 445-452. [CrossRef]

39. Baietti, M.F.; Zhang, Z.; Mortier, E.; Melchior, A.; Degeest, G.; Geeraerts, A.; Ivarsson, Y.; Depoortere, F.; Coomans, C.; Vermeiren, E.; et al. Syndecan-syntenin-ALIX regulates the biogenesis of exosomes. Nat. Cell Biol. 2012, 14, 677-685. [CrossRef]

40. Escola, J.M.; Kleijmeer, M.J.; Stoorvogel, W.; Griffith, J.M.; Yoshie, O.; Geuze, H.J. Selective enrichment of tetraspan proteins on the internal vesicles of multivesicular endosomes and on exosomes secreted by human B-lymphocytes. J. Biol. Chem. 1998, 273, 20121-20127. [CrossRef]

41. Trajkovic, K.; Hsu, C.; Chiantia, S.; Rajendran, L.; Wenzel, D.; Wieland, F.; Schwille, P.; Brugger, B.; Simons, M. Ceramide triggers budding of exosome vesicles into multivesicular endosomes. Science 2008, 319, 1244-1247. [CrossRef]

42. Tai, Y.L.; Chen, K.C.; Hsieh, J.T.; Shen, T.L. Exosomes in cancer development and clinical applications. Cancer Sci. 2018, 109, 2364-2374. [CrossRef]

43. Hessvik, N.P.; Llorente, A. Current knowledge on exosome biogenesis and release. Cell Mol. Life Sci. 2018, 75, 193-208. [CrossRef] [PubMed]

44. Hyenne, V.; Apaydin, A.; Rodriguez, D.; Spiegelhalter, C.; Hoff-Yoessle, S.; Diem, M.; Tak, S.; Lefebvre, O.; Schwab, Y.; Goetz, J.G.; et al. RAL-1 controls multivesicular body biogenesis and exosome secretion. J. Cell Biol. 2015, 211, 27-37. [CrossRef] [PubMed]

45. Fader, C.M.; Sanchez, D.G.; Mestre, M.B.; Colombo, M.I. TI-VAMP/VAMP7 and VAMP3/cellubrevin: Two v-SNARE proteins involved in specific steps of the autophagy/multivesicular body pathways. Biochim. Biophys. Acta 2009, 1793, 1901-1916. [CrossRef] [PubMed]

46. Kanemoto, S.; Nitani, R.; Murakami, T.; Kaneko, M.; Asada, R.; Matsuhisa, K.; Saito, A.; Imaizumi, K. Multivesicular body formation enhancement and exosome release during endoplasmic reticulum stress. Biochem. Biophys. Res. Commun. 2016, 480, 166-172. [CrossRef]

47. King, H.W.; Michael, M.Z.; Gleadle, J.M. Hypoxic enhancement of exosome release by breast cancer cells. BMC Cancer 2012, 12, 421. [CrossRef]

48. Xiao, X.; Yu, S.; Li, S.; Wu, J.; Ma, R.; Cao, H.; Zhu, Y.; Feng, J. Exosomes: Decreased sensitivity of lung cancer A549 cells to cisplatin. PLoS ONE 2014, 9, e89534. [CrossRef]

49. Beer, L.; Zimmermann, M.; Mitterbauer, A.; Ellinger, A.; Gruber, F.; Narzt, M.S.; Zellner, M.; Gyongyosi, M.; Madlener, S.; Simader, E.; et al. Analysis of the Secretome of Apoptotic Peripheral Blood Mononuclear Cells: Impact of Released Proteins and Exosomes for Tissue Regeneration. Sci. Rep. 2015, 5, 16662. [CrossRef]

50. Lehmann, B.D.; Paine, M.S.; Brooks, A.M.; McCubrey, J.A.; Renegar, R.H.; Wang, R.; Terrian, D.M. Senescence-associated exosome release from human prostate cancer cells. Cancer Res. 2008, 68, 7864-7871. [CrossRef] [PubMed]

51. Li, B.; Antonyak, M.A.; Zhang, J.; Cerione, R.A. RhoA triggers a specific signaling pathway that generates transforming microvesicles in cancer cells. Oncogene 2012, 31, 4740-4749. [CrossRef]

52. Akers, J.C.; Gonda, D.; Kim, R.; Carter, B.S.; Chen, C.C. Biogenesis of extracellular vesicles (EV): Exosomes, microvesicles, retrovirus-like vesicles, and apoptotic bodies. J. Neurooncol. 2013, 113, 1-11. [CrossRef] 
53. Verderio, C.; Gabrielli, M.; Giussani, P. Role of sphingolipids in the biogenesis and biological activity of extracellular vesicles. J. Lipid Res. 2018, 59, 1325-1340. [CrossRef]

54. Pfrieger, F.W.; Vitale, N. Cholesterol and the journey of extracellular vesicles. J. Lipid Res. 2018, 59, 2255-2261. [CrossRef] [PubMed]

55. Pollet, H.; Conrard, L.; Cloos, A.S.; Tyteca, D. Plasma Membrane Lipid Domains as Platforms for Vesicle Biogenesis and Shedding? Biomolecules 2018, 8, 94. [CrossRef] [PubMed]

56. Caruso, S.; Poon, I.K.H. Apoptotic Cell-Derived Extracellular Vesicles: More Than Just Debris. Front. Immunol. 2018, 9, 1486. [CrossRef] [PubMed]

57. Charras, G.T. A short history of blebbing. J. Microsc. 2008, 231, 466-478. [CrossRef]

58. Cufaro, M.C.; Pieragostino, D.; Lanuti, P.; Rossi, C.; Cicalini, I.; Federici, L.; De Laurenzi, V.; Del Boccio, P. Extracellular Vesicles and Their Potential Use in Monitoring Cancer Progression and Therapy: The Contribution of Proteomics. J. Oncol. 2019, 2019, 1639854. [CrossRef] [PubMed]

59. Abels, E.R.; Breakefield, X.O. Introduction to Extracellular Vesicles: Biogenesis, RNA Cargo Selection, Content, Release, and Uptake. Cell Mol. Neurobiol. 2016, 36, 301-312. [CrossRef]

60. Ostergaard, O.; Nielsen, C.T.; Iversen, L.V.; Jacobsen, S.; Tanassi, J.T.; Heegaard, N.H. Quantitative proteome profiling of normal human circulating microparticles. J. Proteome Res. 2012, 11, 2154-2163. [CrossRef]

61. Doyle, L.M.; Wang, M.Z. Overview of Extracellular Vesicles, Their Origin, Composition, Purpose, and Methods for Exosome Isolation and Analysis. Cells 2019, 8, 727. [CrossRef] [PubMed]

62. Guescini, M.; Genedani, S.; Stocchi, V.; Agnati, L.F. Astrocytes and Glioblastoma cells release exosomes carrying mtDNA. J. Neural Transm. 2010, 117, 1-4. [CrossRef] [PubMed]

63. Gyorgy, B.; Szabo, T.G.; Pasztoi, M.; Pal, Z.; Misjak, P.; Aradi, B.; Laszlo, V.; Pallinger, E.; Pap, E.; Kittel, A.; et al. Membrane vesicles, current state-of-the-art: Emerging role of extracellular vesicles. Cell Mol. Life Sci. 2011, 68, 2667-2688. [CrossRef]

64. Henderson, M.C.; Azorsa, D.O. The genomic and proteomic content of cancer cell-derived exosomes. Front. Oncol. 2012, 2, 38. [CrossRef] [PubMed]

65. Henne, W.M.; Buchkovich, N.J.; Emr, S.D. The ESCRT pathway. Dev. Cell 2011, 21, 77-91. [CrossRef]

66. Witwer, K.W.; Buzas, E.I.; Bemis, L.T.; Bora, A.; Lasser, C.; Lotvall, J.; Nolte-'t Hoen, E.N.; Piper, M.G.; Sivaraman, S.; Skog, J.; et al. Standardization of sample collection, isolation and analysis methods in extracellular vesicle research. J. Extracell. Vesicles 2013, 2, 20360. [CrossRef]

67. Sinha, A.; Ignatchenko, V.; Ignatchenko, A.; Mejia-Guerrero, S.; Kislinger, T. In-depth proteomic analyses of ovarian cancer cell line exosomes reveals differential enrichment of functional categories compared to the NCI 60 proteome. Biochem. Biophys. Res. Commun. 2014, 445, 694-701. [CrossRef]

68. Zoller, M. Tetraspanins: Push and pull in suppressing and promoting metastasis. Nat. Rev. Cancer 2009, 9, 40-55. [CrossRef]

69. Shen, B.; Fang, Y.; Wu, N.; Gould, S.J. Biogenesis of the posterior pole is mediated by the exosome/microvesicle protein-sorting pathway. J. Biol. Chem. 2011, 286, 44162-44176. [CrossRef]

70. Carnino, J.M.; Ni, K.; Jin, Y. Post-translational Modification Regulates Formation and Cargo-Loading of Extracellular Vesicles. Front. Immunol. 2020, 11, 948. [CrossRef]

71. Korenevskii, A.V.; Milyutina, Y.P.; Zhdanova, A.A.; Pyatygina, K.M.; Sokolov, D.I.; Sel'kov, S.A. Mass-Spectrometric Analysis of Proteome of Microvesicles Produced by NK-92 Natural Killer Cells. Bull. Exp. Biol. Med. 2018, 165, 564-571. [CrossRef]

72. Heijnen, H.F.; Schiel, A.E.; Fijnheer, R.; Geuze, H.J.; Sixma, J.J. Activated platelets release two types of membrane vesicles: Microvesicles by surface shedding and exosomes derived from exocytosis of multivesicular bodies and alpha-granules. Blood 1999, 94, 3791-3799. [CrossRef] [PubMed]

73. Di Vizio, D.; Morello, M.; Dudley, A.C.; Schow, P.W.; Adam, R.M.; Morley, S.; Mulholland, D.; Rotinen, M.; Hager, M.H.; Insabato, L.; et al. Large oncosomes in human prostate cancer tissues and in the circulation of mice with metastatic disease. Am. J. Pathol. 2012, 181, 1573-1584. [CrossRef]

74. Morello, M.; Minciacchi, V.R.; de Candia, P.; Yang, J.; Posadas, E.; Kim, H.; Griffiths, D.; Bhowmick, N.; Chung, L.W.; Gandellini, P.; et al. Large oncosomes mediate intercellular transfer of functional microRNA. Cell Cycle 2013, 12, 3526-3536. [CrossRef]

75. Lee, Y.; El Andaloussi, S.; Wood, M.J. Exosomes and microvesicles: Extracellular vesicles for genetic information transfer and gene therapy. Hum. Mol. Genet. 2012, 21, R125-R134. [CrossRef] [PubMed]

76. Skotland, T.; Sagini, K.; Sandvig, K.; Llorente, A. An emerging focus on lipids in extracellular vesicles. Adv. Drug Deliv. Rev. 2020, 159, 308-321. [CrossRef] [PubMed]

77. Llorente, A.; Skotland, T.; Sylvanne, T.; Kauhanen, D.; Rog, T.; Orlowski, A.; Vattulainen, I.; Ekroos, K.; Sandvig, K. Molecular lipidomics of exosomes released by PC-3 prostate cancer cells. Biochim. Biophys. Acta 2013, 1831, 1302-1309. [CrossRef]

78. Wubbolts, R.; Leckie, R.S.; Veenhuizen, P.T.; Schwarzmann, G.; Mobius, W.; Hoernschemeyer, J.; Slot, J.W.; Geuze, H.J.; Stoorvogel, W. Proteomic and biochemical analyses of human B cell-derived exosomes. Potential implications for their function and multivesicular body formation. J. Biol. Chem. 2003, 278, 10963-10972. [CrossRef]

79. Pienimaeki-Roemer, A.; Kuhlmann, K.; Bottcher, A.; Konovalova, T.; Black, A.; Orso, E.; Liebisch, G.; Ahrens, M.; Eisenacher, M.; Meyer, H.E.; et al. Lipidomic and proteomic characterization of platelet extracellular vesicle subfractions from senescent platelets. Transfusion 2015, 55, 507-521. [CrossRef] [PubMed] 
80. Vagner, T.; Spinelli, C.; Minciacchi, V.R.; Balaj, L.; Zandian, M.; Conley, A.; Zijlstra, A.; Freeman, M.R.; Demichelis, F.; De, S.; et al. Large extracellular vesicles carry most of the tumour DNA circulating in prostate cancer patient plasma. J. Extracell. Vesicles 2018, 7, 1505403. [CrossRef]

81. Li, Y.; Zheng, Q.; Bao, C.; Li, S.; Guo, W.; Zhao, J.; Chen, D.; Gu, J.; He, X.; Huang, S. Circular RNA is enriched and stable in exosomes: A promising biomarker for cancer diagnosis. Cell Res. 2015, 25, 981-984. [CrossRef] [PubMed]

82. Nolte-'t Hoen, E.N.; Buermans, H.P.; Waasdorp, M.; Stoorvogel, W.; Wauben, M.H.; 't Hoen, P.A. Deep sequencing of RNA from immune cell-derived vesicles uncovers the selective incorporation of small non-coding RNA biotypes with potential regulatory functions. Nucleic Acids Res. 2012, 40, 9272-9285. [CrossRef] [PubMed]

83. Kim, K.M.; Abdelmohsen, K.; Mustapic, M.; Kapogiannis, D.; Gorospe, M. RNA in extracellular vesicles. Wiley Interdiscip. Rev. RNA 2017, 8, e1413. [CrossRef]

84. Gezer, U.; Ozgur, E.; Cetinkaya, M.; Isin, M.; Dalay, N. Long non-coding RNAs with low expression levels in cells are enriched in secreted exosomes. Cell Biol. Int. 2014, 38, 1076-1079. [CrossRef] [PubMed]

85. Villarroya-Beltri, C.; Gutierrez-Vazquez, C.; Sanchez-Cabo, F.; Perez-Hernandez, D.; Vazquez, J.; Martin-Cofreces, N.; MartinezHerrera, D.J.; Pascual-Montano, A.; Mittelbrunn, M.; Sanchez-Madrid, F. Sumoylated hnRNPA2B1 controls the sorting of miRNAs into exosomes through binding to specific motifs. Nat. Commun. 2013, 4, 2980. [CrossRef] [PubMed]

86. Rana, S.; Zoller, M. Exosome target cell selection and the importance of exosomal tetraspanins: A hypothesis. Biochem. Soc. Trans. 2011, 39, 559-562. [CrossRef]

87. Record, M.; Carayon, K.; Poirot, M.; Silvente-Poirot, S. Exosomes as new vesicular lipid transporters involved in cell-cell communication and various pathophysiologies. Biochim. Biophys. Acta 2014, 1841, 108-120. [CrossRef]

88. Christianson, H.C.; Svensson, K.J.; van Kuppevelt, T.H.; Li, J.P.; Belting, M. Cancer cell exosomes depend on cell-surface heparan sulfate proteoglycans for their internalization and functional activity. Proc. Natl. Acad. Sci. USA 2013, 110, 17380-17385. [CrossRef]

89. Svensson, K.J.; Christianson, H.C.; Wittrup, A.; Bourseau-Guilmain, E.; Lindqvist, E.; Svensson, L.M.; Morgelin, M.; Belting, M. Exosome uptake depends on ERK1/2-heat shock protein 27 signaling and lipid Raft-mediated endocytosis negatively regulated by caveolin-1. J. Biol. Chem. 2013, 288, 17713-17724. [CrossRef]

90. Mulcahy, L.A.; Pink, R.C.; Carter, D.R. Routes and mechanisms of extracellular vesicle uptake. J. Extracell. Vesicles 2014,3 , 24641. [CrossRef]

91. Horibe, S.; Tanahashi, T.; Kawauchi, S.; Murakami, Y.; Rikitake, Y. Mechanism of recipient cell-dependent differences in exosome uptake. BMC Cancer 2018, 18, 47. [CrossRef] [PubMed]

92. Paget, S. The distribution of secondary growths in cancer of the breast. Cancer Metastasis Rev. 1989, 8, 98-101. [CrossRef]

93. Langley, R.R.; Fidler, I.J. The seed and soil hypothesis revisited-The role of tumor-stroma interactions in metastasis to different organs. Int. J. Cancer 2011, 128, 2527-2535. [CrossRef] [PubMed]

94. Popper, H.H. Progression and metastasis of lung cancer. Cancer Metastasis Rev. 2016, 35, 75-91. [CrossRef] [PubMed]

95. Ebert, W.; Muley, T.; Herb, K.P.; Schmidt-Gayk, H. Comparison of bone scintigraphy with bone markers in the diagnosis of bone metastasis in lung carcinoma patients. Anticancer Res. 2004, 24, 3193-3201.

96. Shin, D.Y.; Na, I.I.; Kim, C.H.; Park, S.; Baek, H.; Yang, S.H. EGFR mutation and brain metastasis in pulmonary adenocarcinomas. J. Thorac. Oncol. 2014, 9, 195-199. [CrossRef]

97. Tamura, T.; Kurishima, K.; Nakazawa, K.; Kagohashi, K.; Ishikawa, H.; Satoh, H.; Hizawa, N. Specific organ metastases and survival in metastatic non-small-cell lung cancer. Mol. Clin. Oncol. 2015, 3, 217-221. [CrossRef]

98. Hendriks, L.E.; Smit, E.F.; Vosse, B.A.; Mellema, W.W.; Heideman, D.A.; Bootsma, G.P.; Westenend, M.; Pitz, C.; de Vries, G.J.; Houben, R.; et al. EGFR mutated non-small cell lung cancer patients: More prone to development of bone and brain metastases? Lung Cancer 2014, 84, 86-91. [CrossRef]

99. Wilbertz, T.; Wagner, P.; Petersen, K.; Stiedl, A.C.; Scheble, V.J.; Maier, S.; Reischl, M.; Mikut, R.; Altorki, N.K.; Moch, H.; et al. SOX2 gene amplification and protein overexpression are associated with better outcome in squamous cell lung cancer. Mod. Pathol. 2011, 24, 944-953. [CrossRef]

100. Peinado, H.; Zhang, H.; Matei, I.R.; Costa-Silva, B.; Hoshino, A.; Rodrigues, G.; Psaila, B.; Kaplan, R.N.; Bromberg, J.F.; Kang, Y.; et al. Pre-metastatic niches: Organ-specific homes for metastases. Nat. Rev. Cancer 2017, 17, 302-317. [CrossRef]

101. Tian, W.; Liu, S.; Li, B. Potential Role of Exosomes in Cancer Metastasis. Biomed Res. Int. 2019, 2019, 4649705. [CrossRef] [PubMed]

102. Dos Anjos Pultz, B.; Andres Cordero da Luz, F.; Socorro Faria, S.; Peixoto Ferreira de Souza, L.; Cristina Brigido Tavares, P.; Alonso Goulart, V.; Fontes, W.; Ricardo Goulart, L.; Jose Barbosa Silva, M. The multifaceted role of extracellular vesicles in metastasis: Priming the soil for seeding. Int. J. Cancer 2017, 140, 2397-2407. [CrossRef] [PubMed]

103. Pachmayr, E.; Treese, C.; Stein, U. Underlying Mechanisms for Distant Metastasis-Molecular Biology. Visc. Med. 2017, 33, 11-20. [CrossRef]

104. Thiery, J.P.; Acloque, H.; Huang, R.Y.; Nieto, M.A. Epithelial-mesenchymal transitions in development and disease. Cell 2009, 139, 871-890. [CrossRef] [PubMed]

105. Lauffenburger, D.A.; Horwitz, A.F. Cell migration: A physically integrated molecular process. Cell 1996, 84, 359-369. [CrossRef]

106. Nishida, N.; Yano, H.; Nishida, T.; Kamura, T.; Kojiro, M. Angiogenesis in cancer. Vasc. Health Risk Manag. 2006, 2, $213-219$. [CrossRef]

107. Fidler, I.J. Metastasis: Quantitative analysis of distribution and fate of tumor emboli labeled with 125 I-5-iodo-2'-deoxyuridine. J. Natl. Cancer Inst. 1970, 45, 773-782. 
108. Luzzi, K.J.; MacDonald, I.C.; Schmidt, E.E.; Kerkvliet, N.; Morris, V.L.; Chambers, A.F.; Groom, A.C. Multistep nature of metastatic inefficiency: Dormancy of solitary cells after successful extravasation and limited survival of early micrometastases. Am. J. Pathol. 1998, 153, 865-873. [CrossRef]

109. Pantel, K.; Speicher, M.R. The biology of circulating tumor cells. Oncogene 2016, 35, 1216-1224. [CrossRef]

110. Joyce, J.A.; Pollard, J.W. Microenvironmental regulation of metastasis. Nat. Rev. Cancer 2009, 9, 239-252. [CrossRef]

111. Valastyan, S.; Weinberg, R.A. Tumor metastasis: Molecular insights and evolving paradigms. Cell 2011, 147, 275-292. [CrossRef]

112. Xiao, D.; He, J. Epithelial mesenchymal transition and lung cancer. J. Thorac. Dis. 2010, 2, 154-159. [CrossRef]

113. Morel, A.P.; Lievre, M.; Thomas, C.; Hinkal, G.; Ansieau, S.; Puisieux, A. Generation of breast cancer stem cells through epithelial-mesenchymal transition. PLoS ONE 2008, 3, e2888. [CrossRef]

114. Mani, S.A.; Guo, W.; Liao, M.J.; Eaton, E.N.; Ayyanan, A.; Zhou, A.Y.; Brooks, M.; Reinhard, F.; Zhang, C.C.; Shipitsin, M.; et al. The epithelial-mesenchymal transition generates cells with properties of stem cells. Cell 2008, 133, 704-715. [CrossRef] [PubMed]

115. Polyak, K.; Weinberg, R.A. Transitions between epithelial and mesenchymal states: Acquisition of malignant and stem cell traits. Nat. Rev. Cancer 2009, 9, 265-273. [CrossRef] [PubMed]

116. Huang, R.Y.; Guilford, P.; Thiery, J.P. Early events in cell adhesion and polarity during epithelial-mesenchymal transition. J. Cell Sci. 2012, 125, 4417-4422. [CrossRef] [PubMed]

117. Yilmaz, M.; Christofori, G. EMT, the cytoskeleton, and cancer cell invasion. Cancer Metastasis Rev. 2009, 28, 15-33. [CrossRef]

118. Lamouille, S.; Xu, J.; Derynck, R. Molecular mechanisms of epithelial-mesenchymal transition. Nat. Rev. Mol. Cell Biol. 2014, 15, 178-196. [CrossRef]

119. Mittal, V. Epithelial Mesenchymal Transition in Tumor Metastasis. Annu. Rev. Pathol. 2018, 13, 395-412. [CrossRef]

120. Peinado, H.; Olmeda, D.; Cano, A. Snail, Zeb and bHLH factors in tumour progression: An alliance against the epithelial phenotype? Nat. Rev. Cancer 2007, 7, 415-428. [CrossRef]

121. De Craene, B.; Berx, G. Regulatory networks defining EMT during cancer initiation and progression. Nat. Rev. Cancer 2013, 13, 97-110. [CrossRef] [PubMed]

122. Yilmaz, M.; Christofori, G. Mechanisms of motility in metastasizing cells. Mol. Cancer Res. 2010, 8, 629-642. [CrossRef]

123. McNiven, M.A. Breaking away: Matrix remodeling from the leading edge. Trends Cell Biol. 2013, 23, 16-21. [CrossRef]

124. Kim, H.; Lee, S.; Shin, E.; Seong, K.M.; Jin, Y.W.; Youn, H.; Youn, B. The Emerging Roles of Exosomes as EMT Regulators in Cancer. Cells 2020, 9, 861. [CrossRef] [PubMed]

125. Jin, W. Role of JAK/STAT3 Signaling in the Regulation of Metastasis, the Transition of Cancer Stem Cells, and Chemoresistance of Cancer by Epithelial-Mesenchymal Transition. Cells 2020, 9, 217. [CrossRef] [PubMed]

126. Kundu, S.T.; Byers, L.A.; Peng, D.H.; Roybal, J.D.; Diao, L.; Wang, J.; Tong, P.; Creighton, C.J.; Gibbons, D.L. The miR-200 family and the miR-183 96 182 cluster target Foxf2 to inhibit invasion and metastasis in lung cancers. Oncogene 2016, 35, 173-186. [CrossRef]

127. Bae, G.Y.; Choi, S.J.; Lee, J.S.; Jo, J.; Lee, J.; Kim, J.; Cha, H.J. Loss of E-cadherin activates EGFR-MEK/ERK signaling, which promotes invasion via the ZEB1/MMP2 axis in non-small cell lung cancer. Oncotarget 2013, 4, 2512-2522. [CrossRef] [PubMed]

128. Gopal, S.K.; Greening, D.W.; Rai, A.; Chen, M.; Xu, R.; Shafiq, A.; Mathias, R.A.; Zhu, H.J.; Simpson, R.J. Extracellular vesicles: Their role in cancer biology and epithelial-mesenchymal transition. Biochem. J. 2017, 474, 21-45. [CrossRef]

129. Vella, L.J. The emerging role of exosomes in epithelial-mesenchymal-transition in cancer. Front. Oncol. 2014, 4, 361. [CrossRef]

130. Greening, D.W.; Gopal, S.K.; Mathias, R.A.; Liu, L.; Sheng, J.; Zhu, H.J.; Simpson, R.J. Emerging roles of exosomes during epithelial-mesenchymal transition and cancer progression. Semin. Cell Dev. Biol. 2015, 40, 60-71. [CrossRef]

131. Tao, S.C.; Guo, S.C. Role of extracellular vesicles in tumour microenvironment. Cell Commun. Signal. 2020, 18, 163. [CrossRef]

132. Long, X.; Ye, Y.; Zhang, L.; Liu, P.; Yu, W.; Wei, F.; Ren, X.; Yu, J. IL-8, a novel messenger to cross-link inflammation and tumor EMT via autocrine and paracrine pathways (Review). Int. J. Oncol. 2016, 48, 5-12. [CrossRef] [PubMed]

133. Scheel, C.; Eaton, E.N.; Li, S.H.; Chaffer, C.L.; Reinhardt, F.; Kah, K.J.; Bell, G.; Guo, W.; Rubin, J.; Richardson, A.L.; et al. Paracrine and autocrine signals induce and maintain mesenchymal and stem cell states in the breast. Cell 2011, 145, 926-940. [CrossRef] [PubMed]

134. Tang, Y.T.; Huang, Y.Y.; Li, J.H.; Qin, S.H.; Xu, Y.; An, T.X.; Liu, C.C.; Wang, Q.; Zheng, L. Alterations in exosomal miRNA profile upon epithelial-mesenchymal transition in human lung cancer cell lines. BMC Genom. 2018, 19, 802. [CrossRef] [PubMed]

135. He, S.; Li, Z.; Yu, Y.; Zeng, Q.; Cheng, Y.; Ji, W.; Xia, W.; Lu, S. Exosomal miR-499a-5p promotes cell proliferation, migration and EMT via mTOR signaling pathway in lung adenocarcinoma. Exp. Cell Res. 2019, 379, 203-213. [CrossRef]

136. Xia, Y.; Wei, K.; Hu, L.Q.; Zhou, C.R.; Lu, Z.B.; Zhan, G.S.; Pan, X.L.; Pan, C.F.; Wang, J.; Wen, W.; et al. Exosome-mediated transfer of miR-1260b promotes cell invasion through Wnt/beta-catenin signaling pathway in lung adenocarcinoma. J. Cell Physiol. 2020, 235, 6843-6853. [CrossRef]

137. Chen, X.; Meng, J.; Yue, W.; Yu, J.; Yang, J.; Yao, Z.; Zhang, L. Fibulin-3 suppresses Wnt/beta-catenin signaling and lung cancer invasion. Carcinogenesis 2014, 35, 1707-1716. [CrossRef] [PubMed]

138. Lanzillotti, C.; De Mattei, M.; Mazziotta, C.; Taraballi, F.; Rotondo, J.C.; Tognon, M.; Martini, F. Long Non-coding RNAs and MicroRNAs Interplay in Osteogenic Differentiation of Mesenchymal Stem Cells. Front. Cell Dev. Biol. 2021, 9, 646032. [CrossRef]

139. Wu, S.; Pan, Y.; Mao, Y.; Chen, Y.; He, Y. Current progress and mechanisms of bone metastasis in lung cancer: A narrative review. Transl. Lung Cancer Res. 2021, 10, 439-451. [CrossRef] 
140. Wu, H.; Zhou, J.; Mei, S.; Wu, D.; Mu, Z.; Chen, B.; Xie, Y.; Ye, Y.; Liu, J. Circulating exosomal microRNA-96 promotes cell proliferation, migration and drug resistance by targeting LMO7. J. Cell Mol. Med. 2017, 21, 1228-1236. [CrossRef]

141. Wu, D.M.; Deng, S.H.; Liu, T.; Han, R.; Zhang, T.; Xu, Y. TGF-beta-mediated exosomal lnc-MMP2-2 regulates migration and invasion of lung cancer cells to the vasculature by promoting MMP2 expression. Cancer Med. 2018, 7, 5118-5129. [CrossRef]

142. Zhang, R.; Xia, Y.; Wang, Z.; Zheng, J.; Chen, Y.; Li, X.; Wang, Y.; Ming, H. Serum long non coding RNA MALAT-1 protected by exosomes is up-regulated and promotes cell proliferation and migration in non-small cell lung cancer. Biochem. Biophys. Res. Commun. 2017, 490, 406-414. [CrossRef]

143. Rahman, M.A.; Barger, J.F.; Lovat, F.; Gao, M.; Otterson, G.A.; Nana-Sinkam, P. Lung cancer exosomes as drivers of epithelial mesenchymal transition. Oncotarget 2016, 7, 54852-54866. [CrossRef] [PubMed]

144. Qiao, Z.; Zhang, Y.; Ge, M.; Liu, S.; Jiang, X.; Shang, Z.; Liu, H.; Cao, C.; Xiao, H. Cancer Cell Derived Small Extracellular Vesicles Contribute to Recipient Cell Metastasis Through Promoting HGF/c-Met Pathway. Mol. Cell Proteom. 2019, 18, 1619-1629. [CrossRef]

145. Holmgren, L.; O’Reilly, M.S.; Folkman, J. Dormancy of micrometastases: Balanced proliferation and apoptosis in the presence of angiogenesis suppression. Nat. Med. 1995, 1, 149-153. [CrossRef] [PubMed]

146. Parangi, S.; O’Reilly, M.; Christofori, G.; Holmgren, L.; Grosfeld, J.; Folkman, J.; Hanahan, D. Antiangiogenic therapy of transgenic mice impairs de novo tumor growth. Proc. Natl. Acad. Sci. USA 1996, 93, 2002-2007. [CrossRef] [PubMed]

147. Folkman, J. Tumor angiogenesis: Therapeutic implications. N. Engl. J. Med. 1971, 285, 1182-1186. [CrossRef]

148. Masoud, G.N.; Li, W. HIF-1alpha pathway: Role, regulation and intervention for cancer therapy. Acta Pharm. Sin. B 2015, 5, 378-389. [CrossRef] [PubMed]

149. Petrova, V.; Annicchiarico-Petruzzelli, M.; Melino, G.; Amelio, I. The hypoxic tumour microenvironment. Oncogenesis 2018, 7, 10. [CrossRef]

150. Semenza, G.L. HIF-1 and human disease: One highly involved factor. Genes Dev. 2000, 14, 1983-1991.

151. Saponaro, C.; Malfettone, A.; Ranieri, G.; Danza, K.; Simone, G.; Paradiso, A.; Mangia, A. VEGF, HIF-1alpha expression and MVD as an angiogenic network in familial breast cancer. PLoS ONE 2013, 8, e53070. [CrossRef]

152. Li, T.; Zhu, Y.; Han, L.; Ren, W.; Liu, H.; Qin, C. VEGFR-1 activation-induced MMP-9-dependent invasion in hepatocellular carcinoma. Future Oncol. 2015, 11, 3143-3157. [CrossRef] [PubMed]

153. Pufe, T.; Harde, V.; Petersen, W.; Goldring, M.B.; Tillmann, B.; Mentlein, R. Vascular endothelial growth factor (VEGF) induces matrix metalloproteinase expression in immortalized chondrocytes. J. Pathol. 2004, 202, 367-374. [CrossRef]

154. Wang, Z.; Chen, J.Q.; Liu, J.L.; Tian, L. Exosomes in tumor microenvironment: Novel transporters and biomarkers. J. Transl. Med. 2016, 14, 297. [CrossRef] [PubMed]

155. Kosaka, N.; Iguchi, H.; Hagiwara, K.; Yoshioka, Y.; Takeshita, F.; Ochiya, T. Neutral sphingomyelinase 2 (nSMase2)-dependent exosomal transfer of angiogenic microRNAs regulate cancer cell metastasis. J. Biol. Chem. 2013, 288, 10849-10859. [CrossRef] [PubMed]

156. Zhang, L.; Zhang, S.; Yao, J.; Lowery, F.J.; Zhang, Q.; Huang, W.C.; Li, P.; Li, M.; Wang, X.; Zhang, C.; et al. Microenvironmentinduced PTEN loss by exosomal microRNA primes brain metastasis outgrowth. Nature 2015, 527, 100-104. [CrossRef]

157. Wang, Y.; Dong, L.; Zhong, H.; Yang, L.; Li, Q.; Su, C.; Gu, W.; Qian, Y. Extracellular Vesicles (EVs) from Lung Adenocarcinoma Cells Promote Human Umbilical Vein Endothelial Cell (HUVEC) Angiogenesis through Yes Kinase-associated Protein (YAP) Transport. Int. J. Biol. Sci. 2019, 15, 2110-2118. [CrossRef]

158. Wang, Y.; Dong, Q.; Zhang, Q.; Li, Z.; Wang, E.; Qiu, X. Overexpression of yes-associated protein contributes to progression and poor prognosis of non-small-cell lung cancer. Cancer Sci. 2010, 101, 1279-1285. [CrossRef] [PubMed]

159. Marti, P.; Stein, C.; Blumer, T.; Abraham, Y.; Dill, M.T.; Pikiolek, M.; Orsini, V.; Jurisic, G.; Megel, P.; Makowska, Z.; et al. YAP promotes proliferation, chemoresistance, and angiogenesis in human cholangiocarcinoma through TEAD transcription factors. Hepatology 2015, 62, 1497-1510. [CrossRef]

160. Zhou, Z.; Zhu, J.S.; Gao, C.P.; Li, L.P.; Zhou, C.; Wang, H.; Liu, X.G. siRNA targeting YAP gene inhibits gastric carcinoma growth and tumor metastasis in SCID mice. Oncol. Lett. 2016, 11, 2806-2814. [CrossRef]

161. Baker, C.H.; Kedar, D.; McCarty, M.F.; Tsan, R.; Weber, K.L.; Bucana, C.D.; Fidler, I.J. Blockade of epidermal growth factor receptor signaling on tumor cells and tumor-associated endothelial cells for therapy of human carcinomas. Am. J. Pathol. 2002, 161, 929-938. [CrossRef]

162. De Luca, A.; Carotenuto, A.; Rachiglio, A.; Gallo, M.; Maiello, M.R.; Aldinucci, D.; Pinto, A.; Normanno, N. The role of the EGFR signaling in tumor microenvironment. J. Cell Physiol. 2008, 214, 559-567. [CrossRef] [PubMed]

163. Amin, D.N.; Hida, K.; Bielenberg, D.R.; Klagsbrun, M. Tumor endothelial cells express epidermal growth factor receptor (EGFR) but not ErbB3 and are responsive to EGF and to EGFR kinase inhibitors. Cancer Res. 2006, 66, 2173-2180. [CrossRef] [PubMed]

164. Al-Nedawi, K.; Meehan, B.; Kerbel, R.S.; Allison, A.C.; Rak, J. Endothelial expression of autocrine VEGF upon the uptake of tumor-derived microvesicles containing oncogenic EGFR. Proc. Natl. Acad. Sci. USA 2009, 106, 3794-3799. [CrossRef] [PubMed]

165. Cui, S.Y.; Wang, R.; Chen, L.B. MicroRNA-145: A potent tumour suppressor that regulates multiple cellular pathways. J. Cell Mol. Med. 2014, 18, 1913-1926. [CrossRef]

166. He, Z.; Yi, J.; Liu, X.; Chen, J.; Han, S.; Jin, L.; Chen, L.; Song, H. MiR-143-3p functions as a tumor suppressor by regulating cell proliferation, invasion and epithelial-mesenchymal transition by targeting QKI-5 in esophageal squamous cell carcinoma. Mol. Cancer 2016, 15, 51. [CrossRef] 
167. Lawson, J.; Dickman, C.; MacLellan, S.; Towle, R.; Jabalee, J.; Lam, S.; Garnis, C. Selective secretion of microRNAs from lung cancer cells via extracellular vesicles promotes CAMK1D-mediated tube formation in endothelial cells. Oncotarget 2017, 8, 83913-83924. [CrossRef]

168. Lawson, J.; Dickman, C.; Towle, R.; Jabalee, J.; Javer, A.; Garnis, C. Extracellular vesicle secretion of miR-142-3p from lung adenocarcinoma cells induces tumor promoting changes in the stroma through cell-cell communication. Mol. Carcinog. 2019, 58, 376-387. [CrossRef]

169. Cheng, Y.; Dai, X.; Yang, T.; Zhang, N.; Liu, Z.; Jiang, Y. Low Long Noncoding RNA Growth Arrest-Specific Transcript 5 Expression in the Exosomes of Lung Cancer Cells Promotes Tumor Angiogenesis. J. Oncol. 2019, 2019, 2476175. [CrossRef]

170. Hsu, Y.L.; Hung, J.Y.; Chang, W.A.; Lin, Y.S.; Pan, Y.C.; Tsai, P.H.; Wu, C.Y.; Kuo, P.L. Hypoxic lung cancer-secreted exosomal miR-23a increased angiogenesis and vascular permeability by targeting prolyl hydroxylase and tight junction protein $\mathrm{ZO}-1$. Oncogene 2017, 36, 4929-4942. [CrossRef]

171. Chen, X.; Ba, Y.; Ma, L.; Cai, X.; Yin, Y.; Wang, K.; Guo, J.; Zhang, Y.; Chen, J.; Guo, X.; et al. Characterization of microRNAs in serum: A novel class of biomarkers for diagnosis of cancer and other diseases. Cell Res. 2008, 18, 997-1006. [CrossRef] [PubMed]

172. Kulshreshtha, R.; Ferracin, M.; Wojcik, S.E.; Garzon, R.; Alder, H.; Agosto-Perez, F.J.; Davuluri, R.; Liu, C.G.; Croce, C.M.; Negrini, M.; et al. A microRNA signature of hypoxia. Mol. Cell Biol. 2007, 27, 1859-1867. [CrossRef] [PubMed]

173. Zheng, Y.; Liu, L.; Chen, C.; Ming, P.; Huang, Q.; Li, C.; Cao, D.; Xu, X.; Ge, W. The extracellular vesicles secreted by lung cancer cells in radiation therapy promote endothelial cell angiogenesis by transferring miR-23a. PeerJ 2017, 5, e3627. [CrossRef] [PubMed]

174. Okumura, N.; Yoshida, H.; Kitagishi, Y.; Murakami, M.; Nishimura, Y.; Matsuda, S. PI3K/AKT/PTEN Signaling as a Molecular Target in Leukemia Angiogenesis. Adv. Hematol. 2012, 2012, 843085. [CrossRef] [PubMed]

175. Kessler, T.; Sahm, F.; Blaes, J.; Osswald, M.; Rubmann, P.; Milford, D.; Urban, S.; Jestaedt, L.; Heiland, S.; Bendszus, M.; et al. Glioma cell VEGFR-2 confers resistance to chemotherapeutic and antiangiogenic treatments in PTEN-deficient glioblastoma. Oncotarget 2015, 6, 31050-31068. [CrossRef]

176. Zhao, Y.; Xu, Y.; Li, Y.; Xu, W.; Luo, F.; Wang, B.; Pang, Y.; Xiang, Q.; Zhou, J.; Wang, X.; et al. NF-kappaB-mediated inflammation leading to EMT via miR-200c is involved in cell transformation induced by cigarette smoke extract. Toxicol. Sci. 2013, 135, 265-276. [CrossRef]

177. Liu, Y.; Luo, F.; Wang, B.; Li, H.; Xu, Y.; Liu, X.; Shi, L.; Lu, X.; Xu, W.; Lu, L.; et al. STAT3-regulated exosomal miR-21 promotes angiogenesis and is involved in neoplastic processes of transformed human bronchial epithelial cells. Cancer Lett. 2016, 370, 125-135. [CrossRef]

178. Qi, Z.; Yang, D.Y.; Cao, J. Increased micro-RNA 17, 21, and 192 gene expressions improve early diagnosis in non-small cell lung cancer. Med. Oncol. 2014, 31, 195. [CrossRef]

179. Zheng, W.; Zhao, J.; Tao, Y.; Guo, M.; Ya, Z.; Chen, C.; Qin, N.; Zheng, J.; Luo, J.; Xu, L. MicroRNA-21: A promising biomarker for the prognosis and diagnosis of non-small cell lung cancer. Oncol. Lett. 2018, 16, 2777-2782. [CrossRef]

180. Raimondo, S.; Pucci, M.; Alessandro, R.; Fontana, S. Extracellular Vesicles and Tumor-Immune Escape: Biological Functions and Clinical Perspectives. Int. J. Mol. Sci. 2020, 21, 2286. [CrossRef]

181. Talmadge, J.E.; Gabrilovich, D.I. History of myeloid-derived suppressor cells. Nat. Rev. Cancer 2013, 13, 739-752. [CrossRef] [PubMed]

182. Alipoor, S.D.; Mortaz, E.; Varahram, M.; Movassaghi, M.; Kraneveld, A.D.; Garssen, J.; Adcock, I.M. The Potential Biomarkers and Immunological Effects of Tumor-Derived Exosomes in Lung Cancer. Front. Immunol. 2018, 9, 819. [CrossRef] [PubMed]

183. Szajnik, M.; Czystowska, M.; Szczepanski, M.J.; Mandapathil, M.; Whiteside, T.L. Tumor-derived microvesicles induce, expand and up-regulate biological activities of human regulatory T cells (Treg). PLoS ONE 2010, 5, e11469. [CrossRef] [PubMed]

184. Huang, S.H.; Li, Y.; Zhang, J.; Rong, J.; Ye, S. Epidermal growth factor receptor-containing exosomes induce tumor-specific regulatory T cells. Cancer Investig. 2013, 31, 330-335. [CrossRef] [PubMed]

185. Yin, Y.; Cai, X.; Chen, X.; Liang, H.; Zhang, Y.; Li, J.; Wang, Z.; Chen, X.; Zhang, W.; Yokoyama, S.; et al. Tumor-secreted miR-214 induces regulatory T cells: A major link between immune evasion and tumor growth. Cell Res. 2014, 24, 1164-1180. [CrossRef] [PubMed]

186. Maimela, N.R.; Liu, S.; Zhang, Y. Fates of CD8+ T cells in Tumor Microenvironment. Comput. Struct. Biotechnol. J. 2019, 17, 1-13. [CrossRef]

187. Pascual-Garcia, M.; Bertolo, C.; Nieto, J.C.; Serrat, N.; Espinosa, I.; D’Angelo, E.; Munoz, R.; Rovira, R.; Vidal, S.; Prat, J. CD8 down-regulation on cytotoxic T lymphocytes of patients with endometrioid endometrial carcinomas. Hum. Pathol. 2016, 56, 180-188. [CrossRef]

188. Prado-Garcia, H.; Romero-Garcia, S.; Aguilar-Cazares, D.; Meneses-Flores, M.; Lopez-Gonzalez, J.S. Tumor-induced CD8+ T-cell dysfunction in lung cancer patients. Clin. Dev. Immunol. 2012, 2012, 741741. [CrossRef]

189. Han, Y.; Liu, D.; Li, L. PD-1/PD-L1 pathway: Current researches in cancer. Am. J. Cancer Res. 2020, 10, 727-742.

190. Theodoraki, M.N.; Yerneni, S.S.; Hoffmann, T.K.; Gooding, W.E.; Whiteside, T.L. Clinical Significance of PD-L1(+) Exosomes in Plasma of Head and Neck Cancer Patients. Clin. Cancer Res. 2018, 24, 896-905. [CrossRef]

191. Muller, L.; Muller-Haegele, S.; Mitsuhashi, M.; Gooding, W.; Okada, H.; Whiteside, T.L. Exosomes isolated from plasma of glioma patients enrolled in a vaccination trial reflect antitumor immune activity and might predict survival. Oncoimmunology 2015, 4, e1008347. [CrossRef] [PubMed] 
192. Li, C.; Li, C.; Zhi, C.; Liang, W.; Wang, X.; Chen, X.; Lv, T.; Shen, Q.; Song, Y.; Lin, D.; et al. Clinical significance of PD-L1 expression in serum-derived exosomes in NSCLC patients. J. Transl. Med. 2019, 17, 355. [CrossRef]

193. Taylor, D.D.; Gercel-Taylor, C.; Lyons, K.S.; Stanson, J.; Whiteside, T.L. T-cell apoptosis and suppression of T-cell receptor/CD3zeta by Fas ligand-containing membrane vesicles shed from ovarian tumors. Clin. Cancer Res. 2003, 9, 5113-5119.

194. Fujita, Y.; Kadota, T.; Araya, J.; Ochiya, T.; Kuwano, K. Extracellular Vesicles: New Players in Lung Immunity. Am. J. Respir. Cell Mol. Biol. 2018, 58, 560-565. [CrossRef]

195. Lin, Y.; Xu, J.; Lan, H. Tumor-associated macrophages in tumor metastasis: Biological roles and clinical therapeutic applications. J. Hematol. Oncol. 2019, 12, 76. [CrossRef] [PubMed]

196. Laoui, D.; Movahedi, K.; Van Overmeire, E.; Van den Bossche, J.; Schouppe, E.; Mommer, C.; Nikolaou, A.; Morias, Y.; De Baetselier, P.; Van Ginderachter, J.A. Tumor-associated macrophages in breast cancer: Distinct subsets, distinct functions. Int. J. Dev. Biol. 2011, 55, 861-867. [CrossRef]

197. Mantovani, A.; Sozzani, S.; Locati, M.; Allavena, P.; Sica, A. Macrophage polarization: Tumor-associated macrophages as a paradigm for polarized M2 mononuclear phagocytes. Trends Immunol. 2002, 23, 549-555. [CrossRef]

198. Song, X.; Ding, Y.; Liu, G.; Yang, X.; Zhao, R.; Zhang, Y.; Zhao, X.; Anderson, G.J.; Nie, G. Cancer Cell-derived Exosomes Induce Mitogen-activated Protein Kinase-dependent Monocyte Survival by Transport of Functional Receptor Tyrosine Kinases. J. Biol. Chem. 2016, 291, 8453-8464. [CrossRef]

199. Leone, K.; Poggiana, C.; Zamarchi, R. The Interplay between Circulating Tumor Cells and the Immune System: From Immune Escape to Cancer Immunotherapy. Diagnostics 2018, 8, 59. [CrossRef]

200. Hanna, N. Role of natural killer cells in control of cancer metastasis. Cancer Metastasis Rev. 1982, 1, 45-64. [CrossRef]

201. Ye, L.; Zhang, F.; Li, H.J.; Yang, L.F.; Lv, T.F.; Gu, W.; Song, Y. Circulating Tumor Cells Were Associated with the Number of T Lymphocyte Subsets and NK Cells in Peripheral Blood in Advanced Non-Small-Cell Lung Cancer. Dis. Markers $2017,2017$. [CrossRef] [PubMed]

202. Alderton, G.K. Exosomes drive premetastatic niche formation. Nat. Rev. Cancer 2012, 12, 447. [CrossRef] [PubMed]

203. Huang, Y.; Song, N.; Ding, Y.; Yuan, S.; Li, X.; Cai, H.; Shi, H.; Luo, Y. Pulmonary vascular destabilization in the premetastatic phase facilitates lung metastasis. Cancer Res. 2009, 69, 7529-7537. [CrossRef] [PubMed]

204. Aguado, B.A.; Bushnell, G.G.; Rao, S.S.; Jeruss, J.S.; Shea, L.D. Engineering the pre-metastatic niche. Nat. Biomed. Eng. 2017, 1, 1-12. [CrossRef] [PubMed]

205. Weidle, U.H.; Birzele, F.; Kollmorgen, G.; Ruger, R. The Multiple Roles of Exosomes in Metastasis. Cancer Genom. Proteom. 2017, 14, 1-15. [CrossRef] [PubMed]

206. McAllister, S.S.; Weinberg, R.A. The tumour-induced systemic environment as a critical regulator of cancer progression and metastasis. Nat. Cell Biol. 2014, 16, 717-727. [CrossRef]

207. Peinado, H.; Lavotshkin, S.; Lyden, D. The secreted factors responsible for pre-metastatic niche formation: Old sayings and new thoughts. Semin. Cancer Biol. 2011, 21, 139-146. [CrossRef]

208. Psaila, B.; Lyden, D. The metastatic niche: Adapting the foreign soil. Nat. Rev. Cancer 2009, 9, 285-293. [CrossRef]

209. Sceneay, J.; Smyth, M.J.; Moller, A. The pre-metastatic niche: Finding common ground. Cancer Metastasis Rev. 2013, 32, 449-464. [CrossRef]

210. Jang, I.; Beningo, K.A. Integrins, CAFs and Mechanical Forces in the Progression of Cancer. Cancers 2019, 11, 721. [CrossRef]

211. Belhabib, I.; Zaghdoudi, S.; Lac, C.; Bousquet, C.; Jean, C. Extracellular Matrices and Cancer-Associated Fibroblasts: Targets for Cancer Diagnosis and Therapy? Cancers 2021, 13, 3466. [CrossRef] [PubMed]

212. Sleeman, J.P. The metastatic niche and stromal progression. Cancer Metastasis Rev. 2012, 31, 429-440. [CrossRef] [PubMed]

213. Kaplan, R.N.; Riba, R.D.; Zacharoulis, S.; Bramley, A.H.; Vincent, L.; Costa, C.; MacDonald, D.D.; Jin, D.K.; Shido, K.; Kerns, S.A.; et al. VEGFR1-positive haematopoietic bone marrow progenitors initiate the pre-metastatic niche. Nature 2005, 438, 820-827. [CrossRef]

214. Lobb, R.J.; Lima, L.G.; Moller, A. Exosomes: Key mediators of metastasis and pre-metastatic niche formation. Semin. Cell Dev. Biol. 2017, 67, 3-10. [CrossRef] [PubMed]

215. Rana, S.; Malinowska, K.; Zoller, M. Exosomal tumor microRNA modulates premetastatic organ cells. Neoplasia 2013, 15, $281-295$. [CrossRef]

216. Zeng, Z.; Li, Y.; Pan, Y.; Lan, X.; Song, F.; Sun, J.; Zhou, K.; Liu, X.; Ren, X.; Wang, F.; et al. Cancer-derived exosomal miR-25-3p promotes pre-metastatic niche formation by inducing vascular permeability and angiogenesis. Nat. Commun. 2018, 9, 5395. [CrossRef]

217. Janowska-Wieczorek, A.; Wysoczynski, M.; Kijowski, J.; Marquez-Curtis, L.; Machalinski, B.; Ratajczak, J.; Ratajczak, M.Z. Microvesicles derived from activated platelets induce metastasis and angiogenesis in lung cancer. Int. J. Cancer 2005, 113, 752-760. [CrossRef]

218. Duan, S.; Nordmeier, S.; Byrnes, A.E.; Buxton, I.L.O. Extracellular Vesicle-Mediated Purinergic Signaling Contributes to Host Microenvironment Plasticity and Metastasis in Triple Negative Breast Cancer. Int. J. Mol. Sci. 2021, 22, 597. [CrossRef]

219. Grange, C.; Tapparo, M.; Collino, F.; Vitillo, L.; Damasco, C.; Deregibus, M.C.; Tetta, C.; Bussolati, B.; Camussi, G. Microvesicles released from human renal cancer stem cells stimulate angiogenesis and formation of lung premetastatic niche. Cancer Res. 2011, 71, 5346-5356. [CrossRef] 
220. Xu, Z.H.; Miao, Z.W.; Jiang, Q.Z.; Gan, D.X.; Wei, X.G.; Xue, X.Z.; Li, J.Q.; Zheng, F.; Qin, X.X.; Fang, W.G.; et al. Brain microvascular endothelial cell exosome-mediated S100A16 up-regulation confers small-cell lung cancer cell survival in brain. FASEB J. 2019, 33, 1742-1757. [CrossRef]

221. Fabbri, M.; Paone, A.; Calore, F.; Galli, R.; Gaudio, E.; Santhanam, R.; Lovat, F.; Fadda, P.; Mao, C.; Nuovo, G.J.; et al. MicroRNAs bind to Toll-like receptors to induce prometastatic inflammatory response. Proc. Natl. Acad. Sci. USA 2012, 109, E2110-E2116. [CrossRef] [PubMed]

222. Liu, Y.; Gu, Y.; Han, Y.; Zhang, Q.; Jiang, Z.; Zhang, X.; Huang, B.; Xu, X.; Zheng, J.; Cao, X. Tumor Exosomal RNAs Promote Lung Pre-metastatic Niche Formation by Activating Alveolar Epithelial TLR3 to Recruit Neutrophils. Cancer Cell 2016, 30, 243-256. [CrossRef] [PubMed]

223. Hoshino, A.; Costa-Silva, B.; Shen, T.L.; Rodrigues, G.; Hashimoto, A.; Tesic Mark, M.; Molina, H.; Kohsaka, S.; Di Giannatale, A.; Ceder, S.; et al. Tumour exosome integrins determine organotropic metastasis. Nature 2015, 527, 329-335. [CrossRef]

224. Liu, Y.; Fan, J.; Xu, T.; Ahmadinejad, N.; Hess, K.; Lin, S.H.; Zhang, J.; Liu, X.; Liu, L.; Ning, B.; et al. Extracellular vesicle tetraspanin-8 level predicts distant metastasis in non-small cell lung cancer after concurrent chemoradiation. Sci. Adv. 2020, 6, eaaz6162. [CrossRef] [PubMed]

225. Lu, J.; Li, J.; Liu, S.; Wang, T.; Ianni, A.; Bober, E.; Braun, T.; Xiang, R.; Yue, S. Exosomal tetraspanins mediate cancer metastasis by altering host microenvironment. Oncotarget 2017, 8, 62803-62815. [CrossRef] [PubMed]

226. Hsu, Y.L.; Huang, M.S.; Hung, J.Y.; Chang, W.A.; Tsai, Y.M.; Pan, Y.C.; Lin, Y.S.; Tsai, H.P.; Kuo, P.L. Bone-marrow-derived cell-released extracellular vesicle miR-92a regulates hepatic pre-metastatic niche in lung cancer. Oncogene 2020, 39, 739-753. [CrossRef]

227. Eichler, A.F.; Chung, E.; Kodack, D.P.; Loeffler, J.S.; Fukumura, D.; Jain, R.K. The biology of brain metastases-translation to new therapies. Nat. Rev. Clin. Oncol. 2011, 8, 344-356. [CrossRef] [PubMed]

228. Rodrigues, G.; Hoshino, A.; Kenific, C.M.; Matei, I.R.; Steiner, L.; Freitas, D.; Kim, H.S.; Oxley, P.R.; Scandariato, I.; Casanova-Salas, I.; et al. Tumour exosomal CEMIP protein promotes cancer cell colonization in brain metastasis. Nat. Cell Biol. 2019, 21, 1403-1412. [CrossRef]

229. Hurwitz, S.N.; Rider, M.A.; Bundy, J.L.; Liu, X.; Singh, R.K.; Meckes, D.G., Jr. Proteomic profiling of NCI-60 extracellular vesicles uncovers common protein cargo and cancer type-specific biomarkers. Oncotarget 2016, 7, 86999-87015. [CrossRef]

230. Sandfeld-Paulsen, B.; Aggerholm-Pedersen, N.; Baek, R.; Jakobsen, K.R.; Meldgaard, P.; Folkersen, B.H.; Rasmussen, T.R.; Varming, K.; Jorgensen, M.M.; Sorensen, B.S. Exosomal proteins as prognostic biomarkers in non-small cell lung cancer. Mol. Oncol. 2016, 10, 1595-1602. [CrossRef]

231. Wang, N.; Song, X.; Liu, L.; Niu, L.; Wang, X.; Song, X.; Xie, L. Circulating exosomes contain protein biomarkers of metastatic non-small-cell lung cancer. Cancer Sci. 2018, 109, 1701-1709. [CrossRef]

232. Sandfeld-Paulsen, B.; Jakobsen, K.R.; Baek, R.; Folkersen, B.H.; Rasmussen, T.R.; Meldgaard, P.; Varming, K.; Jorgensen, M.M.; Sorensen, B.S. Exosomal Proteins as Diagnostic Biomarkers in Lung Cancer. J. Thorac. Oncol. 2016, 11, 1701-1710. [CrossRef] [PubMed]

233. Le, P.; Romano, G.; Nana-Sinkam, P.; Acunzo, M. Non-Coding RNAs in Cancer Diagnosis and Therapy: Focus on Lung Cancer. Cancers 2021, 13, 1372. [CrossRef] [PubMed]

234. Mohrmann, L.; Huang, H.J.; Hong, D.S.; Tsimberidou, A.M.; Fu, S.; Piha-Paul, S.A.; Subbiah, V.; Karp, D.D.; Naing, A.; Krug, A.; et al. Liquid Biopsies Using Plasma Exosomal Nucleic Acids and Plasma Cell-Free DNA Compared with Clinical Outcomes of Patients with Advanced Cancers. Clin. Cancer Res. 2018, 24, 181-188. [CrossRef]

235. Hur, J.Y.; Kim, H.J.; Lee, J.S.; Choi, C.M.; Lee, J.C.; Jung, M.K.; Pack, C.G.; Lee, K.Y. Extracellular vesicle-derived DNA for performing EGFR genotyping of NSCLC patients. Mol. Cancer 2018, 17, 15. [CrossRef] [PubMed]

236. Zhou, Q.; Huang, S.X.; Zhang, F.; Li, S.J.; Liu, C.; Xi, Y.Y.; Wang, L.; Wang, X.; He, Q.Q.; Sun, C.C.; et al. MicroRNAs: A novel potential biomarker for diagnosis and therapy in patients with non-small cell lung cancer. Cell Prolif. 2017, 50, e12394. [CrossRef] [PubMed]

237. Cazzoli, R.; Buttitta, F.; Di Nicola, M.; Malatesta, S.; Marchetti, A.; Rom, W.N.; Pass, H.I. microRNAs derived from circulating exosomes as noninvasive biomarkers for screening and diagnosing lung cancer. J. Thorac. Oncol. 2013, 8, 1156-1162. [CrossRef] [PubMed]

238. Yu, L.; Todd, N.W.; Xing, L.; Xie, Y.; Zhang, H.; Liu, Z.; Fang, H.; Zhang, J.; Katz, R.L.; Jiang, F. Early detection of lung adenocarcinoma in sputum by a panel of microRNA markers. Int. J. Cancer 2010, 127, 2870-2878. [CrossRef] [PubMed]

239. Nadal, E.; Truini, A.; Nakata, A.; Lin, J.; Reddy, R.M.; Chang, A.C.; Ramnath, N.; Gotoh, N.; Beer, D.G.; Chen, G. A Novel Serum 4-microRNA Signature for Lung Cancer Detection. Sci. Rep. 2015, 5, 12464. [CrossRef] [PubMed]

240. Zhu, W.; Zhou, K.; Zha, Y.; Chen, D.; He, J.; Ma, H.; Liu, X.; Le, H.; Zhang, Y. Diagnostic Value of Serum miR-182, miR-183, miR-210, and miR-126 Levels in Patients with Early-Stage Non-Small Cell Lung Cancer. PLoS ONE 2016, 11, e0153046. [CrossRef] [PubMed]

241. Dejima, H.; Iinuma, H.; Kanaoka, R.; Matsutani, N.; Kawamura, M. Exosomal microRNA in plasma as a non-invasive biomarker for the recurrence of non-small cell lung cancer. Oncol. Lett. 2017, 13, 1256-1263. [CrossRef] [PubMed]

242. Shen, J.; Liu, Z.; Todd, N.W.; Zhang, H.; Liao, J.; Yu, L.; Guarnera, M.A.; Li, R.; Cai, L.; Zhan, M.; et al. Diagnosis of lung cancer in individuals with solitary pulmonary nodules by plasma microRNA biomarkers. BMC Cancer 2011, 11, 374. [CrossRef] [PubMed] 
243. Rabinowits, G.; Gercel-Taylor, C.; Day, J.M.; Taylor, D.D.; Kloecker, G.H. Exosomal microRNA: A diagnostic marker for lung cancer. Clin. Lung Cancer 2009, 10, 42-46. [CrossRef] [PubMed]

244. Li, Y.; Li, W.; Ouyang, Q.; Hu, S.; Tang, J. Detection of lung cancer with blood microRNA-21 expression levels in Chinese population. Oncol. Lett. 2011, 2, 991-994. [CrossRef]

245. Robles, A.I.; Arai, E.; Mathe, E.A.; Okayama, H.; Schetter, A.J.; Brown, D.; Petersen, D.; Bowman, E.D.; Noro, R.; Welsh, J.A.; et al An Integrated Prognostic Classifier for Stage I Lung Adenocarcinoma Based on mRNA, microRNA, and DNA Methylation Biomarkers. J. Thorac. Oncol. 2015, 10, 1037-1048. [CrossRef]

246. Le, H.B.; Zhu, W.Y.; Chen, D.D.; He, J.Y.; Huang, Y.Y.; Liu, X.G.; Zhang, Y.K. Evaluation of dynamic change of serum miR-21 and miR-24 in pre- and post-operative lung carcinoma patients. Med. Oncol. 2012, 29, 3190-3197. [CrossRef]

247. Gao, W.; Lu, X.; Liu, L.; Xu, J.; Feng, D.; Shu, Y. MiRNA-21: A biomarker predictive for platinum-based adjuvant chemotherapy response in patients with non-small cell lung cancer. Cancer Biol. Ther. 2012, 13, 330-340. [CrossRef]

248. Li, B.; Ren, S.; Li, X.; Wang, Y.; Garfield, D.; Zhou, S.; Chen, X.; Su, C.; Chen, M.; Kuang, P.; et al. MiR-21 overexpression is associated with acquired resistance of EGFR-TKI in non-small cell lung cancer. Lung Cancer 2014, 83, 146-153. [CrossRef]

249. Wang, J.; Xue, H.; Zhu, Z.; Gao, J.; Zhao, M.; Ma, Z. Expression of serum exosomal miR-23b-3p in non-small cell lung cancer and its diagnostic efficacy. Oncol. Lett. 2020, 20, 30. [CrossRef]

250. Muller, S.; Janke, F.; Dietz, S.; Sultmann, H. Circulating MicroRNAs as Potential Biomarkers for Lung Cancer. Recent Results Cancer Res. 2020, 215, 299-318. [CrossRef]

251. Zhang, H.; Su, Y.; Xu, F.; Kong, J.; Yu, H.; Qian, B. Circulating microRNAs in relation to EGFR status and survival of lung adenocarcinoma in female non-smokers. PLoS ONE 2013, 8, e81408. [CrossRef]

252. Aushev, V.N.; Zborovskaya, I.B.; Laktionov, K.K.; Girard, N.; Cros, M.P.; Herceg, Z.; Krutovskikh, V. Comparisons of microRNA patterns in plasma before and after tumor removal reveal new biomarkers of lung squamous cell carcinoma. PLoS ONE 2013, 8, e78649. [CrossRef] [PubMed]

253. Sanfiorenzo, C.; Ilie, M.I.; Belaid, A.; Barlesi, F.; Mouroux, J.; Marquette, C.H.; Brest, P.; Hofman, P. Two panels of plasma microRNAs as non-invasive biomarkers for prediction of recurrence in resectable NSCLC. PLoS ONE 2013, 8, e54596. [CrossRef]

254. Wang, Y.; Gu, J.; Roth, J.A.; Hildebrandt, M.A.; Lippman, S.M.; Ye, Y.; Minna, J.D.; Wu, X. Pathway-based serum microRNA profiling and survival in patients with advanced stage non-small cell lung cancer. Cancer Res. 2013, 73, 4801-4809. [CrossRef] [PubMed]

255. Yu, S.L.; Chen, H.Y.; Chang, G.C.; Chen, C.Y.; Chen, H.W.; Singh, S.; Cheng, C.L.; Yu, C.J.; Lee, Y.C.; Chen, H.S.; et al. MicroRNA signature predicts survival and relapse in lung cancer. Cancer Cell 2008, 13, 48-57. [CrossRef]

256. Rao, L.; Luo, L.H.; Luo, L.F.; Chen, S.; Ran, R.Z.; Liu, X.L. Identification of plasma exosomes long non-coding RNA HAGLR and circulating tumor cells as potential prognosis biomarkers in non-small cell lung cancer. Transl. Cancer Res. 2019, 8, $2264-2273$. [CrossRef]

257. Roman-Canal, B.; Moiola, C.P.; Gatius, S.; Bonnin, S.; Ruiz-Miro, M.; Gonzalez, E.; Ojanguren, A.; Recuero, J.L.; Gil-Moreno, A.; Falcon-Perez, J.M.; et al. EV-associated miRNAs from pleural lavage as potential diagnostic biomarkers in lung cancer. Sci. Rep. 2019, 9, 15057. [CrossRef]

258. Zhang, W.; Cai, X.; Yu, J.; Lu, X.; Qian, Q.; Qian, W. Exosome-mediated transfer of lncRNA RP11838N2.4 promotes erlotinib resistance in non-small cell lung cancer. Int. J. Oncol. 2018, 53, 527-538. [CrossRef]

259. Lei, Y.; Guo, W.; Chen, B.; Chen, L.; Gong, J.; Li, W. Tumorreleased lncRNA H19 promotes gefitinib resistance via packaging into exosomes in nonsmall cell lung cancer. Oncol. Rep. 2018, 40, 3438-3446. [CrossRef] [PubMed]

260. Munagala, R.; Aqil, F.; Gupta, R.C. Exosomal miRNAs as biomarkers of recurrent lung cancer. Tumour. Biol. 2016, 37, 10703-10714. [CrossRef]

261. Shan, X.; Zhang, L.; Zhu, D.X.; Zhou, X.; Zhang, H.; Liu, Q.X.; Tang, J.W.; Wen, W.; Wang, T.S.; Zhu, W.; et al. Serum microRNA expression profiling revealing potential diagnostic biomarkers for lung adenocarcinoma. Chin. Med. J. 2020, 133, 2532-2542. [CrossRef] [PubMed]

262. Alipoor, S.D.; Adcock, I.M.; Garssen, J.; Mortaz, E.; Varahram, M.; Mirsaeidi, M.; Velayati, A. The roles of miRNAs as potential biomarkers in lung diseases. Eur. J. Pharmacol. 2016, 791, 395-404. [CrossRef] [PubMed]

263. Pan, J.; Bian, Y.; Cao, Z.; Lei, L.; Pan, J.; Huang, J.; Cai, X.; Lan, X.; Zheng, H. Long noncoding RNA MALAT1 as a candidate serological biomarker for the diagnosis of non-small cell lung cancer: A meta-analysis. Thorac. Cancer 2020, 11, 329-335. [CrossRef] [PubMed]

264. Li, C.; Lv, Y.; Shao, C.; Chen, C.; Zhang, T.; Wei, Y.; Fan, H.; Lv, T.; Liu, H.; Song, Y. Tumor-derived exosomal lncRNA GAS5 as a biomarker for early-stage non-small-cell lung cancer diagnosis. J. Cell Physiol. 2019, 234, 20721-20727. [CrossRef] [PubMed]

265. Romano, G.; Veneziano, D.; Nigita, G.; Nana-Sinkam, S.P. RNA Methylation in ncRNA: Classes, Detection, and Molecular Associations. Front. Genet. 2018, 9, 243. [CrossRef]

266. Barbieri, I.; Kouzarides, T. Role of RNA modifications in cancer. Nat. Rev. Cancer 2020, 20, 303-322. [CrossRef]

267. Nigita, G.; Marceca, G.P.; Tomasello, L.; Distefano, R.; Calore, F.; Veneziano, D.; Romano, G.; Nana-Sinkam, S.P.; Acunzo, M.; Croce, C.M. ncRNA Editing: Functional Characterization and Computational Resources. Methods Mol. Biol. 2019, 1912, 133-174. [CrossRef]

268. Nigita, G.; Distefano, R.; Veneziano, D.; Romano, G.; Rahman, M.; Wang, K.; Pass, H.; Croce, C.M.; Acunzo, M.; Nana-Sinkam, P. Tissue and exosomal miRNA editing in Non-Small Cell Lung Cancer. Sci. Rep. 2018, 8, 10222. [CrossRef] 
269. Romano, G.; Saviana, M.; Le, P.; Li, H.; Micalo, L.; Nigita, G.; Acunzo, M.; Nana-Sinkam, P. Non-Coding RNA Editing in Cancer Pathogenesis. Cancers 2020, 12, 1845. [CrossRef]

270. Li, Y.; Zhang, Y.; Qiu, F.; Qiu, Z. Proteomic identification of exosomal LRG1: A potential urinary biomarker for detecting NSCLC. Electrophoresis 2011, 32, 1976-1983. [CrossRef]

271. Sun, Y.; Huo, C.; Qiao, Z.; Shang, Z.; Uzzaman, A.; Liu, S.; Jiang, X.; Fan, L.Y.; Ji, L.; Guan, X.; et al. Comparative Proteomic Analysis of Exosomes and Microvesicles in Human Saliva for Lung Cancer. J. Proteome Res. 2018, 17, 1101-1107. [CrossRef]

272. Lin, J.; Wang, Y.; Zou, Y.Q.; Chen, X.; Huang, B.; Liu, J.; Xu, Y.M.; Li, J.; Zhang, J.; Yang, W.M.; et al. Differential miRNA expression in pleural effusions derived from extracellular vesicles of patients with lung cancer, pulmonary tuberculosis, or pneumonia. Tumor Biol. 2016, 37, 15835-15845. [CrossRef] [PubMed]

273. Krug, A.K.; Enderle, D.; Karlovich, C.; Priewasser, T.; Bentink, S.; Spiel, A.; Brinkmann, K.; Emenegger, J.; Grimm, D.G.; Castellanos-Rizaldos, E.; et al. Improved EGFR mutation detection using combined exosomal RNA and circulating tumor DNA in NSCLC patient plasma. Ann. Oncol. 2018, 29, 2143. [CrossRef]

274. Moloney, B.M.; Gilligan, K.E.; Joyce, D.P.; O’Neill, C.P.; O’Brien, K.P.; Khan, S.; Glynn, C.L.; Waldron, R.M.; Maguire, C.M.; Holian, E.; et al. Investigating the Potential and Pitfalls of EV-Encapsulated MicroRNAs as Circulating Biomarkers of Breast Cancer. Cells 2020, 9, 141. [CrossRef] [PubMed]

275. Thery, C.; Witwer, K.W.; Aikawa, E.; Alcaraz, M.J.; Anderson, J.D.; Andriantsitohaina, R.; Antoniou, A.; Arab, T.; Archer, F.; Atkin-Smith, G.K.; et al. Minimal information for studies of extracellular vesicles 2018 (MISEV2018): A position statement of the International Society for Extracellular Vesicles and update of the MISEV2014 guidelines. J. Extracell. Vesicles 2018, 7, 1535750. [CrossRef] [PubMed]

276. Brennan, K.; Martin, K.; FitzGerald, S.P.; O'Sullivan, J.; Wu, Y.; Blanco, A.; Richardson, C.; Mc Gee, M.M. A comparison of methods for the isolation and separation of extracellular vesicles from protein and lipid particles in human serum. Sci. Rep. 2020, 10, 1039. [CrossRef]

277. Kosaka, N.; Iguchi, H.; Yoshioka, Y.; Takeshita, F.; Matsuki, Y.; Ochiya, T. Secretory mechanisms and intercellular transfer of microRNAs in living cells. J. Biol. Chem. 2010, 285, 17442-17452. [CrossRef]

278. Yokoi, A.; Yoshioka, Y.; Yamamoto, Y.; Ishikawa, M.; Ikeda, S.I.; Kato, T.; Kiyono, T.; Takeshita, F.; Kajiyama, H.; Kikkawa, F.; et al. Malignant extracellular vesicles carrying MMP1 mRNA facilitate peritoneal dissemination in ovarian cancer. Nat. Commun. 2017, 8, 14470. [CrossRef]

279. Phuyal, S.; Hessvik, N.P.; Skotland, T.; Sandvig, K.; Llorente, A. Regulation of exosome release by glycosphingolipids and flotillins. FEBS J. 2014, 281, 2214-2227. [CrossRef]

280. Li, W.; Hu, Y.; Jiang, T.; Han, Y.; Han, G.; Chen, J.; Li, X. Rab27A regulates exosome secretion from lung adenocarcinoma cells A549: Involvement of EPI64. APMIS 2014, 122, 1080-1087. [CrossRef]

281. Romano, G.; Nigita, G.; Calore, F.; Saviana, M.; Le, P.; Croce, C.M.; Acunzo, M.; Nana-Sinkam, P. MiR-124a Regulates Extracellular Vesicle Release by Targeting GTPase Rabs in Lung Cancer. Front. Oncol. 2020, 10, 1454. [CrossRef] [PubMed]

282. Bobrie, A.; Krumeich, S.; Reyal, F.; Recchi, C.; Moita, L.F.; Seabra, M.C.; Ostrowski, M.; Thery, C. Rab27a supports exosomedependent and -independent mechanisms that modify the tumor microenvironment and can promote tumor progression. Cancer Res. 2012, 72, 4920-4930. [CrossRef] [PubMed]

283. Cho, S.H.; Kuo, I.Y.; Lu, P.F.; Tzeng, H.T.; Lai, W.W.; Su, W.C.; Wang, Y.C. Rab37 mediates exocytosis of secreted frizzled-related protein 1 to inhibit Wnt signaling and thus suppress lung cancer stemness. Cell Death Dis. 2018, 9, 868. [CrossRef] [PubMed]

284. Catalano, M.; O'Driscoll, L. Inhibiting extracellular vesicles formation and release: A review of EV inhibitors. J. Extracell. Vesicles 2020, 9, 1703244. [CrossRef] [PubMed]

285. Chalmin, F.; Ladoire, S.; Mignot, G.; Vincent, J.; Bruchard, M.; Remy-Martin, J.P.; Boireau, W.; Rouleau, A.; Simon, B.; Lanneau, D.; et al. Membrane-associated Hsp72 from tumor-derived exosomes mediates STAT3-dependent immunosuppressive function of mouse and human myeloid-derived suppressor cells. J. Clin. Investig. 2010, 120, 457-471. [CrossRef] [PubMed]

286. Hazan-Halevy, I.; Rosenblum, D.; Weinstein, S.; Bairey, O.; Raanani, P.; Peer, D. Cell-specific uptake of mantle cell lymphomaderived exosomes by malignant and non-malignant B-lymphocytes. Cancer Lett. 2015, 364, 59-69. [CrossRef]

287. Kawamoto, T.; Ohga, N.; Akiyama, K.; Hirata, N.; Kitahara, S.; Maishi, N.; Osawa, T.; Yamamoto, K.; Kondoh, M.; Shindoh, M.; et al. Tumor-derived microvesicles induce proangiogenic phenotype in endothelial cells via endocytosis. PLoS ONE 2012, 7, e34045. [CrossRef]

288. Li, X.Q.; Liu, J.T.; Fan, L.L.; Liu, Y.; Cheng, L.; Wang, F.; Yu, H.Q.; Gao, J.; Wei, W.; Wang, H.; et al. Exosomes derived from gefitinibtreated EGFR-mutant lung cancer cells alter cisplatin sensitivity via up-regulating autophagy. Oncotarget 2016, 7, 24585-24595. [CrossRef]

289. Li, X.; Corbett, A.L.; Taatizadeh, E.; Tasnim, N.; Little, J.P.; Garnis, C.; Daugaard, M.; Guns, E.; Hoorfar, M.; Li, I.T.S. Challenges and opportunities in exosome research-Perspectives from biology, engineering, and cancer therapy. APL Bioeng. $2019,3,011503$. [CrossRef]

290. Saunderson, S.C.; Dunn, A.C.; Crocker, P.R.; McLellan, A.D. CD169 mediates the capture of exosomes in spleen and lymph node. Blood 2014, 123, 208-216. [CrossRef]

291. Laulagnier, K.; Javalet, C.; Hemming, F.J.; Chivet, M.; Lachenal, G.; Blot, B.; Chatellard, C.; Sadoul, R. Amyloid precursor protein products concentrate in a subset of exosomes specifically endocytosed by neurons. Cell Mol. Life Sci. 2018, 75, 757-773. [CrossRef] [PubMed] 
292. Rana, S.; Yue, S.; Stadel, D.; Zoller, M. Toward tailored exosomes: The exosomal tetraspanin web contributes to target cell selection. Int. J. Biochem. Cell Biol. 2012, 44, 1574-1584. [CrossRef] [PubMed]

293. Murphy, D.E.; de Jong, O.G.; Brouwer, M.; Wood, M.J.; Lavieu, G.; Schiffelers, R.M.; Vader, P. Extracellular vesicle-based therapeutics: Natural versus engineered targeting and trafficking. Exp. Mol. Med. 2019, 51, 1-12. [CrossRef] [PubMed]

294. Morishita, M.; Takahashi, Y.; Nishikawa, M.; Takakura, Y. Pharmacokinetics of Exosomes-An Important Factor for Elucidating the Biological Roles of Exosomes and for the Development of Exosome-Based Therapeutics. J. Pharm. Sci. 2017, 106, 2265-2269. [CrossRef]

295. Wiklander, O.P.; Nordin, J.Z.; O’Loughlin, A.; Gustafsson, Y.; Corso, G.; Mager, I.; Vader, P.; Lee, Y.; Sork, H.; Seow, Y.; et al. Extracellular vesicle in vivo biodistribution is determined by cell source, route of administration and targeting. J. Extracell. Vesicles 2015, 4, 26316. [CrossRef] [PubMed]

296. Charoenviriyakul, C.; Takahashi, Y.; Morishita, M.; Nishikawa, M.; Takakura, Y. Role of Extracellular Vesicle Surface Proteins in the Pharmacokinetics of Extracellular Vesicles. Mol. Pharm. 2018, 15, 1073-1080. [CrossRef] [PubMed]

297. Kaur, S.; Singh, S.P.; Elkahloun, A.G.; Wu, W.; Abu-Asab, M.S.; Roberts, D.D. CD47-dependent immunomodulatory and angiogenic activities of extracellular vesicles produced by T cells. Matrix Biol. 2014, 37, 49-59. [CrossRef]

298. Kamerkar, S.; LeBleu, V.S.; Sugimoto, H.; Yang, S.; Ruivo, C.F.; Melo, S.A.; Lee, J.J.; Kalluri, R. Exosomes facilitate therapeutic targeting of oncogenic KRAS in pancreatic cancer. Nature 2017, 546, 498-503. [CrossRef]

299. Kibria, G.; Ramos, E.K.; Lee, K.E.; Bedoyan, S.; Huang, S.; Samaeekia, R.; Athman, J.J.; Harding, C.V.; Lotvall, J.; Harris, L.; et al. A rapid, automated surface protein profiling of single circulating exosomes in human blood. Sci. Rep. 2016, 6, 36502. [CrossRef]

300. Zhang, W.; Huang, Q.; Xiao, W.; Zhao, Y.; Pi, J.; Xu, H.; Zhao, H.; Xu, J.; Evans, C.E.; Jin, H. Advances in Anti-Tumor Treatments Targeting the CD47/SIRPalpha Axis. Front. Immunol. 2020, 11, 18. [CrossRef]

301. Kaur, S.; Elkahloun, A.G.; Singh, S.P.; Arakelyan, A.; Roberts, D.D. A function-blocking CD47 antibody modulates extracellular vesicle-mediated intercellular signaling between breast carcinoma cells and endothelial cells. J. Cell Commun. Signal. 2018, 12, 157-170. [CrossRef] [PubMed]

302. Koh, E.; Lee, E.J.; Nam, G.H.; Hong, Y.; Cho, E.; Yang, Y.; Kim, I.S. Exosome-SIRPalpha, a CD47 blockade increases cancer cell phagocytosis. Biomaterials 2017, 121, 121-129. [CrossRef] [PubMed]

303. Suk, J.S.; Xu, Q.; Kim, N.; Hanes, J.; Ensign, L.M. PEGylation as a strategy for improving nanoparticle-based drug and gene delivery. Adv. Drug Deliv. Rev. 2016, 99, 28-51. [CrossRef] [PubMed]

304. Kooijmans, S.A.A.; Fliervoet, L.A.L.; van der Meel, R.; Fens, M.; Heijnen, H.F.G.; en Henegouwen, P.V.B.; Vader, P.; Schiffelers, R.M. PEGylated and targeted extracellular vesicles display enhanced cell specificity and circulation time. J. Control. Release 2016, 224, 77-85. [CrossRef]

305. Sadeghzadeh, M.; Bornehdeli, S.; Mohahammadrezakhani, H.; Abolghasemi, M.; Poursaei, E.; Asadi, M.; Zafari, V.; AghebatiMaleki, L.; Shanehbandi, D. Dendritic cell therapy in cancer treatment; the state-of-the-art. Life Sci. 2020, 254, 117580. [CrossRef] [PubMed]

306. Suek, N.; Campesato, L.F.; Merghoub, T.; Khalil, D.N. Targeted APC Activation in Cancer Immunotherapy to Enhance the Abscopal Effect. Front. Immunol. 2019, 10, 604. [CrossRef] [PubMed]

307. Pitt, J.M.; Andre, F.; Amigorena, S.; Soria, J.C.; Eggermont, A.; Kroemer, G.; Zitvogel, L. Dendritic cell-derived exosomes for cancer therapy. J. Clin. Investig. 2016, 126, 1224-1232. [CrossRef] [PubMed]

308. Pullan, J.E.; Confeld, M.I.; Osborn, J.K.; Kim, J.; Sarkar, K.; Mallik, S. Exosomes as Drug Carriers for Cancer Therapy. Mol. Pharm. 2019, 16, 1789-1798. [CrossRef]

309. Liu, H.; Chen, L.; Liu, J.; Meng, H.; Zhang, R.; Ma, L.; Wu, L.; Yu, S.; Shi, F.; Li, Y.; et al. Co-delivery of tumor-derived exosomes with alpha-galactosylceramide on dendritic cell-based immunotherapy for glioblastoma. Cancer Lett. 2017, 411, 182-190. [CrossRef]

310. Meng, W.; He, C.; Hao, Y.; Wang, L.; Li, L.; Zhu, G. Prospects and challenges of extracellular vesicle-based drug delivery system: Considering cell source. Drug Deliv. 2020, 27, 585-598. [CrossRef]

311. Sabado, R.L.; Balan, S.; Bhardwaj, N. Dendritic cell-based immunotherapy. Cell Res. 2017, 27, 74-95. [CrossRef]

312. Saeedi, P.; Halabian, R.; Imani Fooladi, A.A. A revealing review of mesenchymal stem cells therapy, clinical perspectives and Modification strategies. Stem Cell Investig. 2019, 6, 34. [CrossRef] [PubMed]

313. Yamashita, T.; Takahashi, Y.; Takakura, Y. Possibility of Exosome-Based Therapeutics and Challenges in Production of Exosomes Eligible for Therapeutic Application. Biol. Pharm. Bull. 2018, 41, 835-842. [CrossRef] [PubMed]

314. Wen, D.; Peng, Y.; Liu, D.; Weizmann, Y.; Mahato, R.I. Mesenchymal stem cell and derived exosome as small RNA carrier and Immunomodulator to improve islet transplantation. J. Control. Release 2016, 238, 166-175. [CrossRef]

315. Mancuso, P.; Raman, S.; Glynn, A.; Barry, F.; Murphy, J.M. Mesenchymal Stem Cell Therapy for Osteoarthritis: The Critical Role of the Cell Secretome. Front. Bioeng. Biotechnol. 2019, 7, 9. [CrossRef]

316. Jo, J.I.; Gao, J.Q.; Tabata, Y. Biomaterial-based delivery systems of nucleic acid for regenerative research and regenerative therapy. Regen. Ther. 2019, 11, 123-130. [CrossRef] [PubMed]

317. Perets, N.; Betzer, O.; Shapira, R.; Brenstein, S.; Angel, A.; Sadan, T.; Ashery, U.; Popovtzer, R.; Offen, D. Golden Exosomes Selectively Target Brain Pathologies in Neurodegenerative and Neurodevelopmental Disorders. Nano Lett. 2019, 19, 3422-3431. [CrossRef] 
318. Vakhshiteh, F.; Atyabi, F.; Ostad, S.N. Mesenchymal stem cell exosomes: A two-edged sword in cancer therapy. Int. J. Nanomed. 2019, 14, 2847-2859. [CrossRef]

319. Zhou, J.; Tan, X.; Tan, Y.; Li, Q.; Ma, J.; Wang, G. Mesenchymal Stem Cell Derived Exosomes in Cancer Progression, Metastasis and Drug Delivery: A Comprehensive Review. J. Cancer 2018, 9, 3129-3137. [CrossRef]

320. Kim, M.S.; Haney, M.J.; Zhao, Y.; Yuan, D.; Deygen, I.; Klyachko, N.L.; Kabanov, A.V.; Batrakova, E.V. Engineering macrophagederived exosomes for targeted paclitaxel delivery to pulmonary metastases: In vitro and in vivo evaluations. Nanomedicine 2018, 14, 195-204. [CrossRef]

321. Guo, M.; Wu, F.; Hu, G.; Chen, L.; Xu, J.; Xu, P.; Wang, X.; Li, Y.; Liu, S.; Zhang, S.; et al. Autologous tumor cell-derived microparticle-based targeted chemotherapy in lung cancer patients with malignant pleural effusion. Sci. Transl. Med. $2019,11$. [CrossRef]

322. Bose, R.J.C.; Uday Kumar, S.; Zeng, Y.; Afjei, R.; Robinson, E.; Lau, K.; Bermudez, A.; Habte, F.; Pitteri, S.J.; Sinclair, R.; et al. Tumor Cell-Derived Extracellular Vesicle-Coated Nanocarriers: An Efficient Theranostic Platform for the Cancer-Specific Delivery of Anti-miR-21 and Imaging Agents. ACS Nano 2018, 12, 10817-10832. [CrossRef] [PubMed]

323. Jafari, D.; Shajari, S.; Jafari, R.; Mardi, N.; Gomari, H.; Ganji, F.; Forouzandeh Moghadam, M.; Samadikuchaksaraei, A. Designer Exosomes: A New Platform for Biotechnology Therapeutics. BioDrugs 2020, 34, 567-586. [CrossRef] [PubMed]

324. Alvarez-Erviti, L.; Seow, Y.; Yin, H.; Betts, C.; Lakhal, S.; Wood, M.J. Delivery of siRNA to the mouse brain by systemic injection of targeted exosomes. Nat. Biotechnol. 2011, 29, 341-345. [CrossRef] [PubMed]

325. Mentkowski, K.I.; Lang, J.K. Exosomes Engineered to Express a Cardiomyocyte Binding Peptide Demonstrate Improved Cardiac Retention in Vivo. Sci. Rep. 2019, 9, 10041. [CrossRef]

326. Kim, H.; Yun, N.; Mun, D.; Kang, J.Y.; Lee, S.H.; Park, H.; Park, H.; Joung, B. Cardiac-specific delivery by cardiac tissue-targeting peptide-expressing exosomes. Biochem. Biophys. Res. Commun. 2018, 499, 803-808. [CrossRef]

327. Kooijmans, S.A.; Aleza, C.G.; Roffler, S.R.; van Solinge, W.W.; Vader, P.; Schiffelers, R.M. Display of GPI-anchored anti-EGFR nanobodies on extracellular vesicles promotes tumour cell targeting. J. Extracell. Vesicles 2016, 5, 31053. [CrossRef]

328. Ohno, S.; Takanashi, M.; Sudo, K.; Ueda, S.; Ishikawa, A.; Matsuyama, N.; Fujita, K.; Mizutani, T.; Ohgi, T.; Ochiya, T.; et al. Systemically injected exosomes targeted to EGFR deliver antitumor microRNA to breast cancer cells. Mol. Ther. 2013, 21, 185-191. [CrossRef]

329. Pi, F.; Binzel, D.W.; Lee, T.J.; Li, Z.; Sun, M.; Rychahou, P.; Li, H.; Haque, F.; Wang, S.; Croce, C.M.; et al. Nanoparticle orientation to control RNA loading and ligand display on extracellular vesicles for cancer regression. Nat. Nanotechnol. 2018, 13, 82-89. [CrossRef]

330. Wang, Y.; Chen, X.; Tian, B.; Liu, J.; Yang, L.; Zeng, L.; Chen, T.; Hong, A.; Wang, X. Nucleolin-targeted Extracellular Vesicles as a Versatile Platform for Biologics Delivery to Breast Cancer. Theranostics 2017, 7, 1360-1372. [CrossRef]

331. Qi, H.; Liu, C.; Long, L.; Ren, Y.; Zhang, S.; Chang, X.; Qian, X.; Jia, H.; Zhao, J.; Sun, J.; et al. Blood Exosomes Endowed with Magnetic and Targeting Properties for Cancer Therapy. ACS Nano 2016, 10, 3323-3333. [CrossRef]

332. Elsharkasy, O.M.; Nordin, J.Z.; Hagey, D.W.; de Jong, O.G.; Schiffelers, R.M.; Andaloussi, S.E.; Vader, P. Extracellular vesicles as drug delivery systems: Why and how? Adv. Drug Deliv. Rev. 2020, 159, 332-343. [CrossRef]

333. Zhang, Z.; Dombroski, J.A.; King, M.R. Engineering of Exosomes to Target Cancer Metastasis. Cell Mol. Bioeng. 2020, 13, 1-16. [CrossRef]

334. Yuan, Z.; Kolluri, K.K.; Gowers, K.H.; Janes, S.M. TRAIL delivery by MSC-derived extracellular vesicles is an effective anticancer therapy. J. Extracell. Vesicles 2017, 6, 1265291. [CrossRef]

335. Lou, G.; Song, X.; Yang, F.; Wu, S.; Wang, J.; Chen, Z.; Liu, Y. Exosomes derived from miR-122-modified adipose tissue-derived MSCs increase chemosensitivity of hepatocellular carcinoma. J. Hematol. Oncol. 2015, 8, 122. [CrossRef] [PubMed]

336. Mendt, M.; Kamerkar, S.; Sugimoto, H.; McAndrews, K.M.; Wu, C.C.; Gagea, M.; Yang, S.; Blanko, E.V.R.; Peng, Q.; Ma, X.; et al. Generation and testing of clinical-grade exosomes for pancreatic cancer. JCI Insight 2018, 3, e99263. [CrossRef] [PubMed]

337. Ma, Y.; Dong, S.; Li, X.; Kim, B.Y.S.; Yang, Z.; Jiang, W. Extracellular Vesicles: An Emerging Nanoplatform for Cancer Therapy. Front. Oncol. 2020, 10, 606906. [CrossRef]

338. Li, S.P.; Lin, Z.X.; Jiang, X.Y.; Yu, X.Y. Exosomal cargo-loading and synthetic exosome-mimics as potential therapeutic tools. Acta Pharmacol. Sin. 2018, 39, 542-551. [CrossRef] [PubMed]

339. Yang, Z.; Shi, J.; Xie, J.; Wang, Y.; Sun, J.; Liu, T.; Zhao, Y.; Zhao, X.; Wang, X.; Ma, Y.; et al. Large-scale generation of functional mRNA-encapsulating exosomes via cellular nanoporation. Nat. Biomed. Eng. 2020, 4, 69-83. [CrossRef] 